\title{
Mitigation of Power Quality Issues Due to High Penetration of Renewable Energy Sources in Electric Grid Systems Using Three-Phase APF/STATCOM Technologies: A Review
}

\author{
Wajahat Ullah Khan Tareen ${ }^{1,2, *}$, Muhammad Aamir ${ }^{3}$, Saad Mekhilef ${ }^{1}$ (D), Mutsuo Nakaoka ${ }^{1}$, \\ Mehdi Seyedmahmoudian 4 (iD), Ben Horan ${ }^{5}$ (D), Mudasir Ahmed Memon 1 (i) \\ and Nauman Anwar Baig ${ }^{2}$ \\ 1 Power Electronics and Renewable Energy Research Laboratory (PEARL), Department of \\ Electrical Engineering, University of Malaya, Kuala Lumpur 50603, Malaysia; saad@um.edu.my (S.M.); \\ nakaoka@pe-news1.eee.yamaguchi-u.ac.jp (M.N.); memon.mudasir@usindh.edu.pk (M.A.M.) \\ 2 Department of Electrical Engineering, International Islamic University, Islamabad 44000, Pakistan; \\ nauman.anwar@iiu.edu.pk \\ 3 Department of Electrical Engineering, Bahria University, Islamabad 44000, Pakistan; \\ muhammadaamir.buic@bahria.edu.pk \\ 4 School of Software and Electrical Engineering, Swinburne University of Technology, VIC 3122, Australia; \\ mseyedmahmoudian@swin.edu.au \\ 5 School of Engineering, Deakin University, Waurn Ponds, VIC 3216, Australia; ben.horan@deakin.edu.au \\ * Correspondence: wajahat.tareen@iiu.edu.pk or wajahattareen@gmail.com; Tel.: +0092-332-574-4848
}

Received: 20 April 2018; Accepted: 23 May 2018; Published: 7 June 2018

\begin{abstract}
This study summarizes an analytical review on the comparison of three-phase static compensator (STATCOM) and active power filter (APF) inverter topologies and their control schemes using industrial standards and advanced high-power configurations. Transformerless and reduced switch count topologies are the leading technologies in power electronics that aim to reduce system cost and offer the additional benefits of small volumetric size, lightweight and compact structure, and high reliability. A detailed comparison of the topologies, control strategies and implementation structures of grid-connected high-power converters is presented. However, reducing the number of power semiconductor devices, sensors, and control circuits requires complex control strategies. This study focuses on different topological devices, namely, passive filters, shunt and hybrid filters, and STATCOMs, which are typically used for power quality improvement. Additionally, appropriate control schemes, such as sinusoidal pulse width modulation (SPWM) and space vector PWM techniques, are selected. According to recent developments in shunt APF/STATCOM inverters, simulation and experimental results prove the effectiveness of APF/STATCOM systems for harmonic mitigation based on the defined limit in IEEE-519.
\end{abstract}

Keywords: FACTS devices; active power filter; static compensator; control strategies; grid-connected converter; SPWM;SVM

\section{Introduction}

Electricity is an indication of comfortable life, and the demand for this energy source is increasing. Development in power industries increases the number of linear and nonlinear loads in each system. In nonlinear load conditions, many solid-state switching converters draw reactive power and current harmonics from the AC grid. These nonlinear loads generate harmonics, which produce disturbance and directly influence human life. Nowadays, each piece of equipment, power system, 
and service, such as furnaces, computer power supplies, communication systems, renewable energy systems, electrical power generations, and high-voltage systems, requires a continuous power supply. Researchers and different power companies are continuously exploring solutions to power quality problems [1], such as harmonics, system imbalance, load balancing, excess neutral current, and power system grid intrusions. Evidently, the increasing demand for nonlinear loads produces harmonics in the power system, thereby resulting in poor power quality. Flexible AC transmission system (FACTS) devices, such as static compensators (STATCOMs) and active power filters (APFs), are the most dominant technologies available for industrial and commercial purposes and are deemed the solution to this power quality problem [2-4].

In the past, harmonic grid problems were solved using passive filter (PF) devices [5]. These filters, together with low-cost solutions for power quality issues, are considered the initial stage of development in mitigating current harmonics [6,7]. APFs are considered the second stage of development and an effective solution to overcome the limitation of PFs. However, the size, cost, and rating of APFs are considerably increased by the increasing demand for power system capacity $[8,9]$. To overcome the issues of shunt APFs, a third stage of development consists of hybrid power filter (HPF) devices, which comprise hybrid combinations of PFs with shunt APFs [10]. Furthermore, HPF technology is evaluated in the fourth stage of development as a unified power quality conditioner (UPQC) [11]. Previous research $[12,13]$ on power quality improvement has led to important developments in FACTS devices, namely, the static volt-ampere reactive (VAR) compensator (SVC), dynamic voltage restorer (DVR), and distribution STATCOM (DSTATCOM) [14-16]. Such improvements compensate for the mitigation problems related to power quality, including poor load power factor, load harmonics, imbalanced load conditions, and DC offset in loads.

Many shunt APFs are impractical for use for high-power-rating components. Therefore, transformerless and reduced switch count topologies are the leading technologies in power electronics that aim to reduce system cost and concurrently provide such benefits as small volumetric size, light weight, remarkably compact structure, and high reliability. Modern APF topologies are rapidly replacing the standard ones because of their effective performance, efficient response, and favorable cost and size attributes. Nevertheless, reducing the number of power semiconductor devices, power conversion circuits, sensors, and control circuits requires complicated control strategies [17,18].

Despite the importance of decreasing the number of power components, no study focuses on reduced switch count topologies and complex control strategies in shunt APFs and STATCOMs [19]. The present study focuses on the comprehensive review of advanced reduced switch count topologies, specifically SAPFs and STATCOMs, control schemes for reconfigurable voltage-fed-type inverters (VSIs). The control structures and possibilities of implementing grid-connected power converters in different reference frames are discussed and compared. Furthermore, the overview of the complete control schemes and enhanced control strategies, including the most appropriate control strategies, such as sinusoidal pulse width modulation (PWM) and space vector PWM techniques, are presented. Comparisons and characteristics of operating reduced switch and leg count VSIs are concluded according to a well-surveyed literature summary. Finally, a summary and recommendations for future research are highlighted.

\section{Harmonics and International Standards}

The amount or penetration of harmonics had previously been largely increasing, thereby affecting the performance and efficiency of the system [20]. Harmonics are generated in the system because of non-linear or critical loads. Harmonics exist in a power grid or power distribution network in the form of series and parallel resonances generated by harmonic current loads, which increase the source voltage and current total harmonic distortion. However, modern technologies in power quality improvement mitigate current, voltage, active and reactive power, voltage zero-crossing, and other issues, such as harmonics, voltage sags and swells, notches and flickers, spikes and glitches, and voltage imbalance [21]. 
Harmonic sources are generally classified into two types on the basis of system impedance, namely, current and voltage types [22]. A diode rectifier with smoothing inductor is categorized as a current harmonic source because it produces the current harmonics at the source side, which is the input of the rectifier. A diode rectifier with smoothing capacitor is a voltage harmonic source, which is affected by the AC-side impedance and generates harmonics at the output of the inverter. Two international standards of IEEE-519, namely, IEEE Recommended Practices and Requirements for Harmonic Control in Electrical Power Systems and IEC 61000-3-2 [23,24], provide limitations and guidelines for manufacturers and power utility companies that are connected to the power grid. These standards address harmonic issues, such as current harmonics, power quality, grounding, and voltage harmonics.

\section{Methods for Mitigating Harmonics}

Different methods are adopted to mitigate harmonic contents in power grid-connected APF systems [25]. PFs, APFs, and STATCOMs are improved technologies that solve harmonic power quality problems [26].

\subsection{Shunt PFs}

PFs were introduced to mitigate harmonic compensation as an initial solution to power quality issues in the power distribution network. This technology presents a simple economical solution that consists of different series and parallel combinations of inductors, capacitors, and damping resistors [27]. Figure 1 shows the commonly used PF configuration [28].
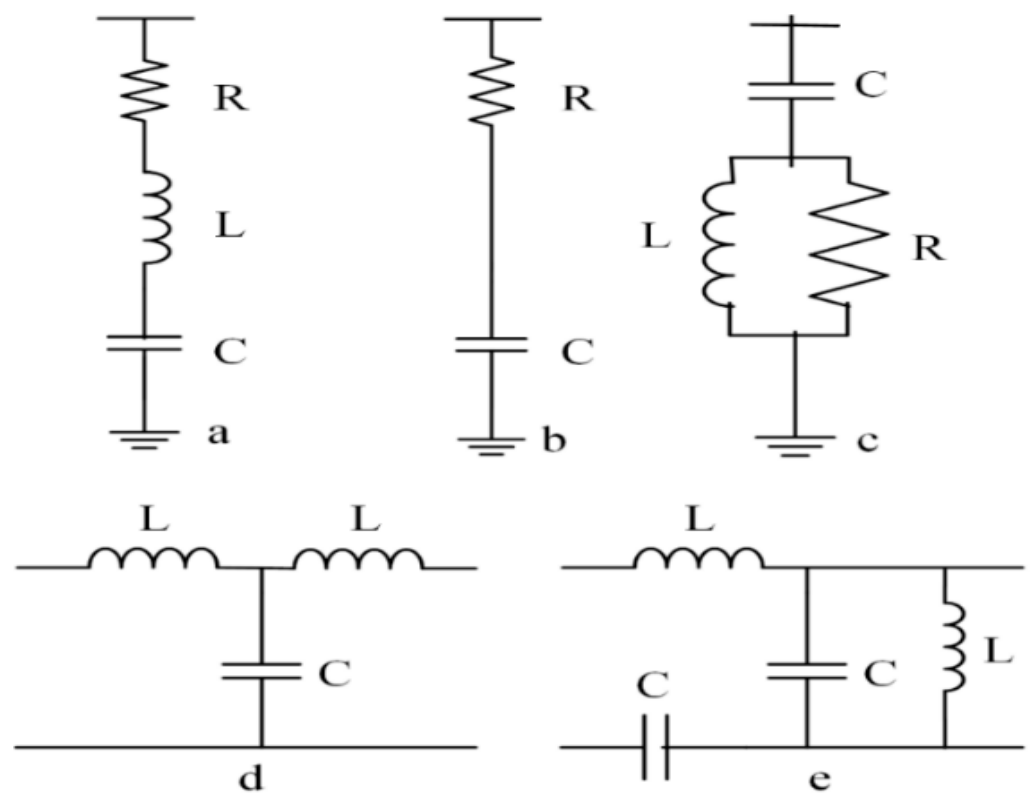

Figure 1. PF structures: (a) single-tuned; (b) first-order high-pass; (c) second-order high-pass; (d) LCL; and (e) LLCC filters.

Each operation is influenced by the fundamental source impedance. The filtering characteristics depend on the values of the inductance and capacitance sets. The operation is tuned according to the required harmonic order, such as first, second, and third order, to track the requisite harmonics. Studies have presented many PF design techniques, such as series, shunt, single-tuned, double-tuned, low-pass, high-pass, bandpass, LCL and LCC filters. The PF configurations are installed in series with the power distribution system to provide high impedance and cancel the flow of harmonic current. PFs are generally coupled with a thyristor-controlled reactor to improve harmonic mitigation and reactive current component compensation. Some of the key practical limitations are as follows: 
- PFs require a separate filter for each harmonic current, and their filtering range is limited.

- PFs allow only one component (either a harmonic or a fundamental current component) to pass at a time.

- Large amounts of harmonic current saturate or overload the filter and cause series resonance with the AC source, thereby resulting in excessive harmonic flow into the PFs.

- PFs amplify source-side harmonic contents because of the impedance in the source of parallel and series negative resonances between the grid and the filter [29].

- The design parameters of PFs in an AC system depend on the system operating frequency, which changes around its nominal value according to variable load conditions.

- PFs only eliminate frequencies to which they are tuned, thus resulting in limited compensation, large size, and tuning issues.

\subsection{Shunt APFs}

APFs were introduced and investigated as a solution to the limitations of PFs. An APF consists of an active switching device and passive-energy storage devices, such as inductors and capacitors, which provide superior compensation characteristics, including voltage and current harmonics, voltage imbalance compensation for utilities, and current imbalance compensation for consumers. APFs mitigate reactive power, neutral current, changing line impedance, frequency variation, voltage notch, sudden voltage distortion, transient disturbance, and voltage balance and improve the power factor of voltage and current in medium-power systems [30].

Different APF topologies and control methodologies have been proposed and progressively investigated as a perceived solution to critical issues in high-power load applications [31,32]. APFs are classified into many categories in accordance to subsequent measures. The circuit structure of an APF commonly includes a voltage-source PWM inverter with a DC-link capacitor. Evidently, current-source APFs are superior in terms of compensating current dynamics. However, voltage-source APFs perform better than current-source APFs in terms of filter losses and PWM carrier harmonic reduction. Table 1 shows the survey results for shunt and series APFs [11].

Table 1. Comparison of active power filters (APFs) in power quality improvement techniques.

\begin{tabular}{|c|c|c|}
\hline Category & Shunt APF & Series APF \\
\hline Connection with system & Parallel with distribution system & Connected in series with distribution system \\
\hline Action & Current source & Voltage source \\
\hline Filter rating & $\begin{array}{l}\text { Voltage rated at full load rating } \\
\text { Current rating comprises partially } \\
\text { harmonic and partly reactive } \\
\text { current components }\end{array}$ & $\begin{array}{l}\text { Current rated at full load rating } \\
\text { Voltage rating is partially compensated } \\
\text { voltage component }\end{array}$ \\
\hline $\begin{array}{l}\text { Characteristics } \\
\text { of compensation }\end{array}$ & $\begin{array}{l}\text { Source impedance exerts no effect } \\
\text { on compensation for current } \\
\text { source loads. }\end{array}$ & $\begin{array}{l}\text { Source and load impedance exert no effect on } \\
\text { compensation for voltage source loads. }\end{array}$ \\
\hline Load considered & $\begin{array}{l}\text { Nonlinear/inductive current } \\
\text { source loads or harmonics } \\
\text { containing current source loads }\end{array}$ & $\begin{array}{l}\text { Nonlinear/capacitive voltage source loads or } \\
\text { harmonics containing voltage source loads }\end{array}$ \\
\hline
\end{tabular}

The basic compensation principle of shunt APFs is eliminating the current harmonics generated by critical loads. Generally, APFs are installed in a shunt position near the nonlinear load to compensate 
for the effect of harmonic nonlinearity [33]. APFs eliminate harmonics by injecting reactive or compensating current at the point of common coupling (PCC) into the power network. Each APF generates inverse harmonics as a mirror image to the nonlinear load harmonics, thereby canceling the harmonics and leaving the fundamental component to make the source current purely sinusoidal, as depicted in Figure 2 [28].

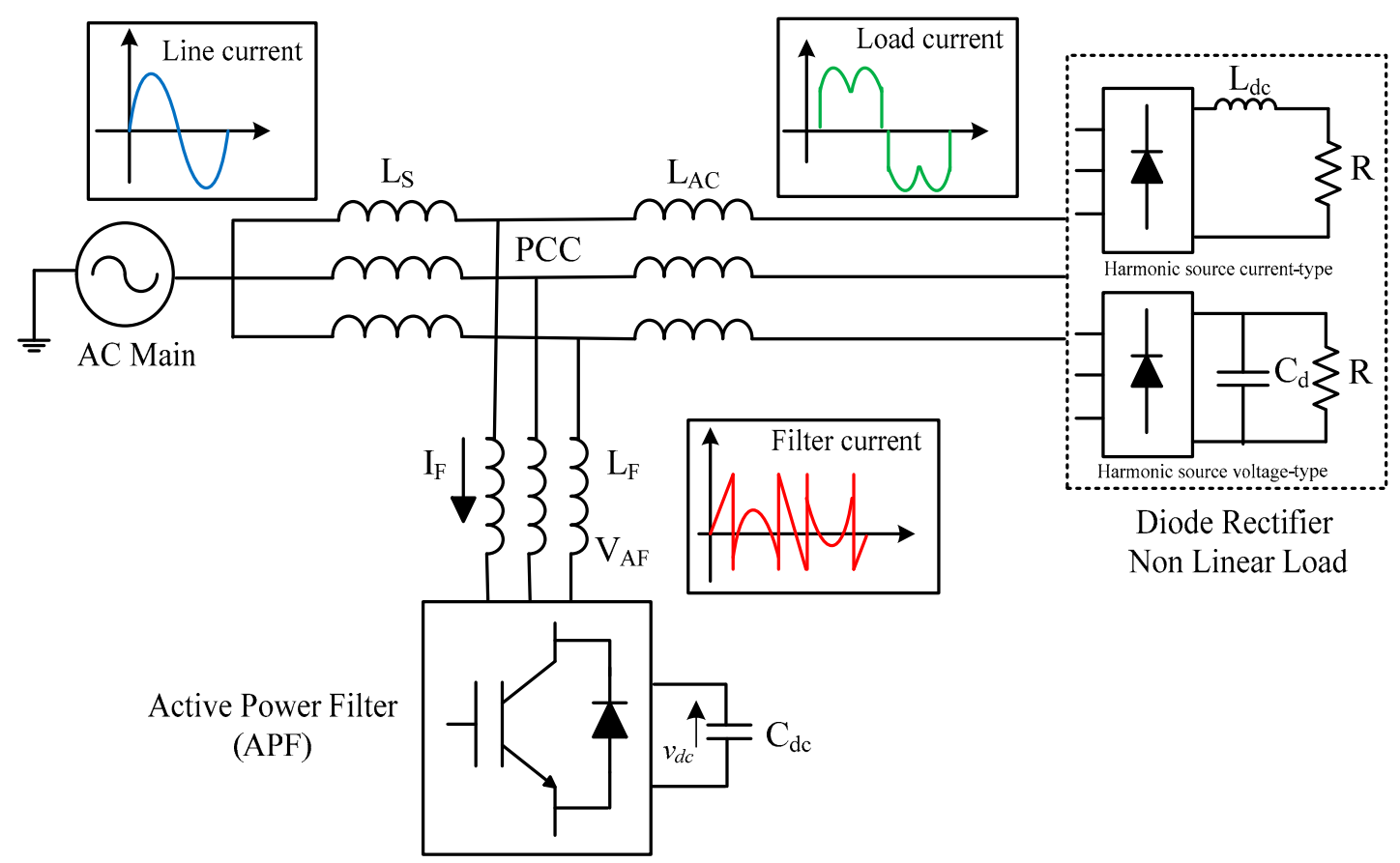

Figure 2. Basic compensation principle of the SAPF.

\subsection{STATCOM}

FACTS devices are increasingly required in modern transmission systems for high-power transfers [34]. Two types of FACTS devices, namely, SVCs and STATCOMs [35], can restore active power current and dynamic reactive power compensation [36]. These devices consist of the modular unit of the voltage source converter (VSC) equipped with insulated-gate bipolar transistors (IGBTs) for rapid switching and controlling using the PWM scheme. A STATCOM is a shunt device that is connected with PCC to provide voltage support and active and reactive power, increase transient stability and improve damping. A brief detailed classification of the FACTS devices is shown in Figure $3[37,38]$.

At the distribution level, STATCOM devices are operated as an active filter to achieve harmonic filtering, power factor correction, neutral current compensation, and load balancing [39]. APFs are an advanced technology that offers faster dynamic response, smaller size, lower system cost, and higher performance under low-voltage oscillations than SVC devices. Energy storage devices improve power quality and provide rapid controllable transient response to the bus voltage by injecting or absorbing the corresponding amount of reactive power into or from the system. Such devices maintain the minimum values of amplitude, phase, and frequency to control voltage flickers during fault events. In addition, the inconsistent flow of reactive power between the supply power grid and the loads is prevented [40]. Table 2 presents the best available solution for the specific compensation challenges [41-43]. 

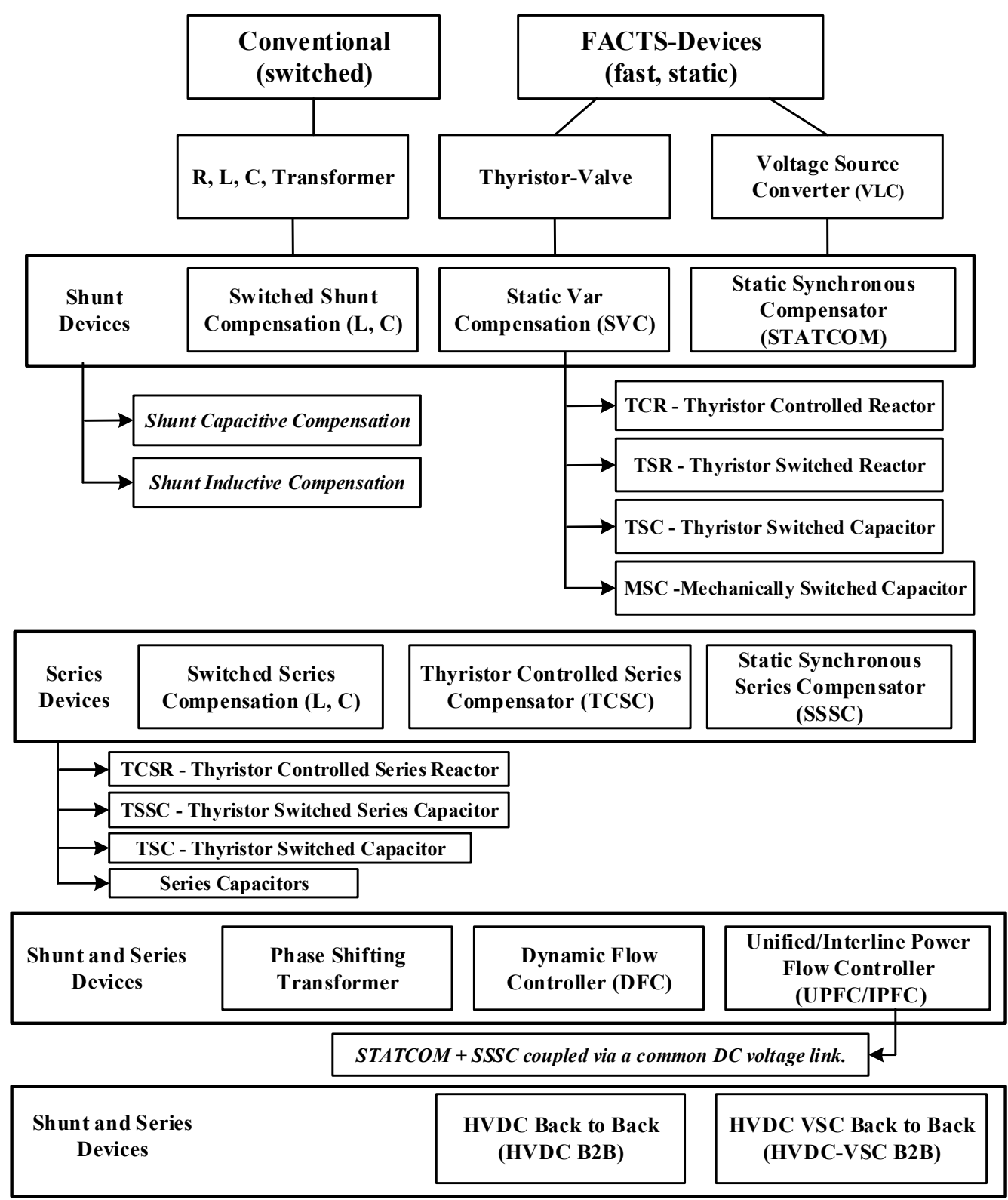

Figure 3. Overview of the major FACTS devices.

The following sections discuss the high penetration of renewable energy sources in the electrical power grid system for reactive power compensation and harmonic mitigation problems.

\subsubsection{Multilevel PV-STATCOM Applications in Grid-Connected Systems}

The conventional two- and three-level inverter configurations are not suitable for photovoltaic (PV) applications in high-power-rating systems [44,45]. Many configurations are inefficient in harvesting maximum power, have a low utilization factor, and require a large $\mathrm{AC}$ filter at the output for high power quality. A grid-connected solar PV power conditioning inverter conventionally requires a transformer for galvanic isolation to match the grid voltages with the inverter output. The concept of PV-STATCOM systems is required to regulate real and reactive power through the converter and mitigate the limitations of conventional PV inverters [46]. The cascaded H-bridge (CHB) inverter in multilevel PV-STATCOMs is an advanced configuration for high-solar-power applications and 
has isolated input DC sources and no additional DC power source requirement for STATCOM devices $[47,48]$.

Table 2. Comparison of the advanced technology solution for the reactive power compensation challenges.

\begin{tabular}{|c|c|c|c|c|c|}
\hline Technology & MSC(DN)/MSR & SVC & $\begin{array}{l}\text { SVC PLUS } \\
\text { (STATCOM) }\end{array}$ & Hybrid STATCOM & $\begin{array}{l}\text { Synchronous } \\
\text { Condenser }\end{array}$ \\
\hline Application & $\begin{array}{l}\text { Compensation of } \\
\text { predictable load }\end{array}$ & $\begin{array}{l}\text { Fast dynamic } \\
\text { compensation and } \\
\text { voltage recovery } \\
\text { during faults }\end{array}$ & $\begin{array}{l}\text { Fast dynamic } \\
\text { compensation and } \\
\text { voltage recovery } \\
\text { during faults }\end{array}$ & $\begin{array}{l}\text { Fast dynamic } \\
\text { compensation and } \\
\text { voltage recovery } \\
\text { during faults }\end{array}$ & $\begin{array}{l}\text { Provision of } \\
\text { short-circuit } \\
\text { power, inertia, } \\
\text { dynamic } \\
\text { compensation, } \\
\text { and voltage } \\
\text { recovery } \\
\text { during faults }\end{array}$ \\
\hline Switching & Limited switching only & Unlimited switching & Unlimited switching & Unlimited switching & $\begin{array}{l}\text { Continuous } \\
\text { operation }\end{array}$ \\
\hline $\begin{array}{l}\mathrm{V} / \mathrm{I} \\
\text { characteristic }\end{array}$ & No response & $\begin{array}{l}\text { Good } \\
\text { overvoltage performance }\end{array}$ & $\begin{array}{l}\text { Superior under } \\
\text { voltage performance }\end{array}$ & $\begin{array}{l}\text { Superior under } \\
\text { voltage performance }\end{array}$ & $\begin{array}{l}\text { Good } \\
\text { overload capability }\end{array}$ \\
\hline Control range & $\begin{array}{l}\text { Adjustable by MSC } \\
\text { and MSR ranges }\end{array}$ & $\begin{array}{l}\text { Adjustable by } \\
\text { branch ranges }\end{array}$ & $\begin{array}{l}\text { Symmetrical output: } \\
\text { Adjustable range }\end{array}$ & $\begin{array}{l}\text { Unsymmetrical output: } \\
\text { Adjustable range }\end{array}$ & $\begin{array}{l}\text { Adjustable by } \\
\text { generator size }\end{array}$ \\
\hline Harmonics & $\begin{array}{l}\text { Susceptible } \\
\text { to harmonics }\end{array}$ & $\begin{array}{l}\text { TCR is source of } \\
\text { harmonics-AC } \\
\text { filters required }\end{array}$ & $\begin{array}{l}\text { Harmonically } \\
\text { self-compensated-no } \\
\text { filters required }\end{array}$ & $\begin{array}{l}\text { Harmonically } \\
\text { self-compensated-no } \\
\text { filters required }\end{array}$ & $\begin{array}{l}\text { Not susceptible } \\
\text { to harmonics }\end{array}$ \\
\hline Response time & $\begin{array}{l}2-5 \text { cycles, depending } \\
\text { on breaker }\end{array}$ & $2-3$ cycles & $1.5-2$ cycles & $1.5-2$ cycles & seconds \\
\hline $\begin{array}{l}\text { Operation } \\
\text { and maintenance }\end{array}$ & $\begin{array}{l}\text { Very low, depending } \\
\text { on breaker }\end{array}$ & $\begin{array}{l}\text { Low, primarily visual } \\
\text { inspection }\end{array}$ & $\begin{array}{l}\text { Very low, primarily } \\
\text { visual inspection }\end{array}$ & $\begin{array}{l}\text { Very low, primarily } \\
\text { visual inspection }\end{array}$ & $\begin{array}{l}\text { Low, inspection } \\
\text { every 3-4 years }\end{array}$ \\
\hline $\begin{array}{l}\text { Losses at } 0 \\
\text { MVAR } \\
\text { output power }\end{array}$ & $0 \%$ & $\begin{array}{l}0.3 \% \text { of the rated output } \\
\text { power }\end{array}$ & $\begin{array}{l}0.15 \% \text { of the rated } \\
\text { output power }\end{array}$ & $\begin{array}{l}0.15 \% \text { of the rated } \\
\text { output power }\end{array}$ & $\begin{array}{l}\sim 1 \% \text { of the rated } \\
\text { output power }\end{array}$ \\
\hline
\end{tabular}

In the study of [49], a PV inverter operated as a STATCOM for the optimal use of the system, provided active power during daytime, when solar energy is available, and provided reactive power when irradiation was low. Similarly, in several studies, PV inverters operated as STATCOMs during daytime to provide the reactive power compensation in a distribution utility network $[50,51]$. However, the performance of the system depends on the rated capacity of the inverter, the constant DC-link voltage, and the maximum power point (MPP) instant time tracking in the distribution utility network [52]. In the study of [53], a PV-STATCOM was adopted with active power filtering against power quality issues in the PV system, such as transient voltages, voltage flickering, and harmonics. Therefore, a PV-active filter-STATCOM is designed for harmonic mitigation and continuous regulation of reactive power for grid applications.

In the study of [54], a SHAPF based on a cascaded H-bridge multilevel inverter (CHB-MLI) was tested for high-power PV applications with reduced filter size, maximized PV cell power extraction, and improved utilization factor through reactive power compensation. With advanced level controls, the PV-STATCOM system can be adopted for active filter applications. Furthermore, PV-STATCOM inverters improve the stability of voltage-sensitive loads during grid fault conditions [55]. In the study of $[56,57]$, a PV-STATCOM without a DC-DC converter was tested; reduced switch count configurations controlled the DC-link voltage through the operation of STATCOM, and the PV-STATCOM system improved the utilization factor and power quality by compensating the reactive power reference in the range of 0-1 P.U. with reduced system size and cost. In study [58] emphasized the necessity of multifunction PV inverters and different active and passive controls in resolving power quality issues. Furthermore, three different controls, namely, $a b c, d-q$, and alpha-beta controls, were discussed with a comparison of suitable topologies on the basis of consumer applications [59]. A brief review of anti-islanding techniques and power quality issues were discussed in the study of [60]. 
A comprehensive review of power quality, stability, and protection and the negative impacts of PV systems due to voltage parameter control and static compensation techniques in the power distribution grid were discussed in the studies of [61,62]. Meanwhile, [63] investigated a CHB-based inverter and modular multilevel converters for STATCOM applications and compared reactive power controls for large PV applications [64].

Independent DC links make CHB-based inverters a suitable candidate for PV and STATCOM applications because of the following advantages: (a) a small filter produces low THD; (b) an output transformer is unnecessary because of the increased number of modules, which extend the output voltage level with low rating; (c) the cost and size of the power components are reduced by the low-voltage-level operation; (d) the cost and size of the power components and auxiliary equipment are reduced because the voltage levels in each module are low. A modified selective harmonic elimination PWM (SHE-PWM) technique was discussed in the study of [65] for a transformerless STATCOM that was tested using the $\mathrm{CHB}$ configuration for grid applications [66,67]. The independent DC-link sources in PV-STATCOM applications reduce system cost. Therefore, the CHB-MLI multilevel configuration with phase-shifted modulation techniques is suitable for large-scale systems [68]. An advanced selective swapping scheme was adopted in a 154-kV 21-level CHB inverter-based STATCOM system to reduce the issue of DC ripple voltage [69].

In the study of [70,71], a sinusoidal voltage waveform was achieved using SHE-PWM. Furthermore, in the study of [72], the sensors at the DC-links were eliminated by adopting the control due to the nonlinear parameter uncertainties presented for the CHB-MLI in the study. Zero-sequence voltage and negative sequence current schemes were tested under one- and two-line faults for a CHB-based STATCOM to reduce switching losses [73]. Another active power balance control scheme was tested to regulate the reactive power for a $\mathrm{CHB}$ inverter; the positive- and negative-sequence control components were monitored for DC-link voltage balance under the balanced or imbalanced conditions of the grid voltage [74]. Therefore, a PV-STATCOM inverter operates on two AC-source controllers at the same frequency level. The sources with high voltage amplitude provide reactive power to the other sources. In this study, the magnitude of the inverter output depends on the reference reactive power signal. Similarly, the sources with leading phase angle provide active power to the other sources. In conclusion, the STATCOM can be used to eliminate harmonics and compensate for lagging and leading VAR.

STATCOM devices aim to provide rapid load voltage regulation along the controllable exchange of reactive power in the system, as well as achieve power quality improvement, reactive power control, voltage regulation, power swing, and improvement of transmission line capacity during power system faults [75]. However, many other power converters, such as DSTATCOMs [76], UPQCs [77], and DVRs [78], also eliminate harmonics and imbalance issues in the generation and utilization of the system $[79,80]$. A DSTATCOM is a synchronous voltage generator or a static synchronous compensator with a coupling transformer, an inverter, and an energy storage device similar to that of the configuration of a STATCOM. The DSTATCOM injects or absorbs uninterrupted capacitive and inductive reactive power into or from the distribution system [81].

The AC-controllable VSC can be used as a multifunction STATCOM with modified control structure to provide harmonic elimination, reactive power, and load imbalance compensation under nonlinear loads and non-ideal main voltage conditions. The potential applications of STATCOM devices such as APFs, are tested for active power filtering, and reactive power supplies are considerably attractive to distribution engineers [82]. Table 3 demonstrates reactive power-compensating devices against various control parameters that are related to the said devices [83,84]. These parameters are automatic voltage control, STATCOM, SVC and thyristor-controlled series capacitor. 
Table 3. Comparison of control parameters affected by reactive power-compensating devices.

\begin{tabular}{|c|c|c|c|c|c|c|c|}
\hline Parameters & Static Capacitors & Capacitor \& Reactor Bank & AVC & STATCOM & SVC & TCSC & UPFC \\
\hline Reactive power & $* *$ & $* * *$ & $* *$ & $* * * *$ & $* * *$ & $* *$ & $* * * * *$ \\
\hline Active power & & $* *$ & $* *$ & $*$ & $*$ & $* *$ & \\
\hline Voltage stability & $* *$ & $* *$ & $* *$ & $* * * *$ & $* * *$ & $* * *$ & $* * * * *$ \\
\hline Voltage control & $* *$ & $* *$ & $* *$ & $* * * *$ & $* * *$ & $* *$ & $* * * * *$ \\
\hline Flicker control & & * & & $* * * *$ & $* * *$ & & $* * * *$ \\
\hline Harmonic reduction & & * & & & & & $* * * *$ \\
\hline Power flow control & & & & & & $* * *$ & $* * * *$ \\
\hline Oscillation damping & & * & & $* * *$ & ** & $* * *$ & $* * * *$ \\
\hline
\end{tabular}

High number of "*" is preferred.

\subsubsection{Wind Turbine STATCOM (WT-STATCOM) Applications in Grid-Connected Systems}

The evolution of power electronic technology has created two generation of FACTS devices in wind farms. These devices are classified into two generations, namely, the old thyristor-type and the advanced VSC-type [38,85], and are used to mitigate voltage instability, reactive power problems [86], and harmonic distortion to improve the power quality of the network [87].

The thyristor-based FACTS devices in wind farms are SVCs. The main structure of the SVC consists of capacitors and inductances that are controlled by thyristors. The STATCOM consists of a main component of modular VSC, which is equipped with IGBTs that are controlled by PWM. Figure 4 shows the structure of an induction generator-based wind turbine and a STATCOM that is connected to a grid and a wind turbine terminal [88]. A coupling transformer is installed to provide galvanic isolation and to control the flow of reactive power during steady- and transient-state conditions [88]. With these modified control strategies, the STATCOMs are superior to other mitigation methods, such as SVCs and series-saturated reactors during normal and transient conditions [89].

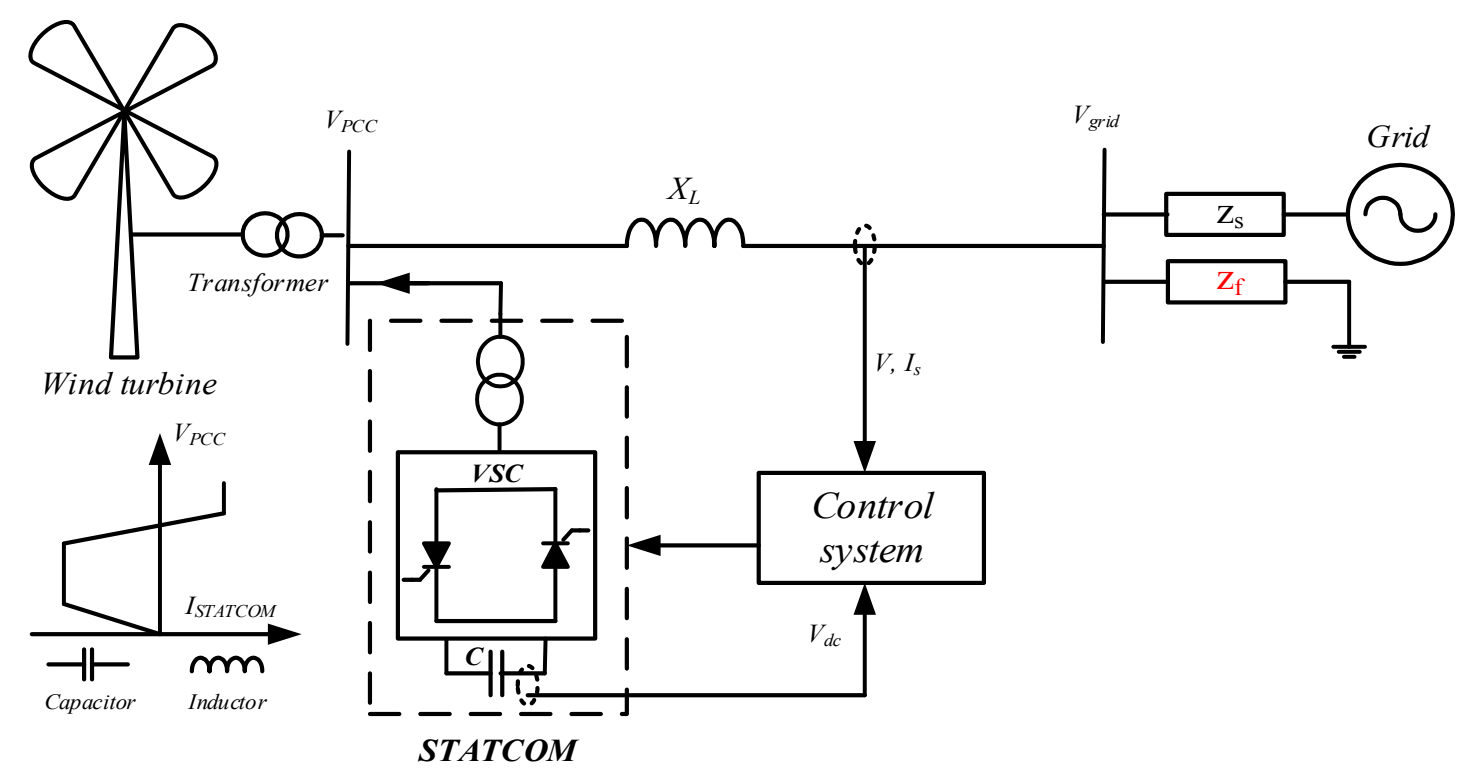

Figure 4. The structure of the WT based FSIG connected to STATCOM.

An energy storage system (ESS) with STATCOM provides a new robust decentralized control operation for high-wind-power applications [90]. The controller operates on the linear quadratic output-feedback method and provides a promising solution for high-wind-power systems [91]. 
Another robust STATCOM control was presented [92], and it controls the active and reactive power and pitch angle of wind turbine induction generators for improved low-voltage ride through (LVRT) capability. The limitation of this control is the enhanced torque produced inside the induction machine, which produces a high maximum torque and stresses the drivetrain during fault recovery. Therefore, an advanced indirect torque control (ITC)-based control is used to limit the maximum torque of the STATCOM controller [93].

In another study [94], the STATCOM and SVC were compared in terms of LVRT development. The STATCOM, which is $15 \%$ cheaper than the SVC, is the more economical solution. In conclusion, SVC devices have limited capabilities at low voltage levels. However, advanced STATCOMs can maintain reactive power output over a wide range of voltages with a smaller structure and faster control response than SVC [94].

Generally, a STATCOM FACTS device is installed for an entire wind farm [86,95], multilevel full H-bridge whereas an SVC-type thyristor-controlled resistor (TCR) device is installed for a single wind turbine. Besides reactive power regulation, these FACTS devices provide isolation and firewall protection to wind turbines against the effects of grid disturbances and connect the wind turbines with low X/R ratio or weak grids [96]. A study [97] therefore used a hybrid electrolyser and fuel cell system to control the ramp rate of wind turbine power and enhance the voltage quality at the PCC. The system stopped the inrush power flows in the electrolyser and the fuel cell path by controlling the frequent start-up and shutdown of the fuel cell stacks, which are effects associated with the grid-connected wind farms. STATCOM-based control methods [98] are adopted to regulate grid reactive power and maintain a suitable level of voltage sag on the grid and prevent the wind turbine from disconnecting from the grid during faults. The unified power flow controller is one of the most advanced FACTS devices used in wind applications and consists of two power converters. One converter controls as a STATCOM and the other operates as a static synchronous series compensator to control power flow with the limitation of high cost $[99,100]$. During grid faults, the reactive power demand can be compensated by an external dynamic STATCOM and an ESS [101], such as hybrid battery-super capacitor energy storage [102]. The ESS system with STATCOM provides a promising solution for wind power system applications [91].

\section{Standard Classification of Shunt APFs}

Generally, APFs are classified into two categories, namely, DC and AC power filters. DC-APFs are designed with a thyristor configuration for high-power drives [55] and high-voltage DC systems. An AC-APF configuration consists of active solutions, such as active power quality and line conditioners and instantaneous reactive power compensators for current and voltage harmonics. Shunt APFs are classified under three categories, namely, topology-, converter-, and phases-type configurations. Topology-type filters can be delegated as shunt, series, and hybrid APFs (HAPFs), as shown in Figure 5.

Converter-type filters are classified as VSI and current-fed-type inverters (CSI). Figure 6a illustrates the configuration of the CSI-APF, a bridge structure topology that consists of a diode that is connected in series with a semiconductor self-commutating switching device (IGBT) [28]. The diode is used for reverse voltage blocking with the interfacing DC energy storage inductor in the system. This topology shows high value losses and requires high-value installed AC power capacitors. Furthermore, the dynamic response time is slow, and additional complex control is required to regulate the harmonic current. 


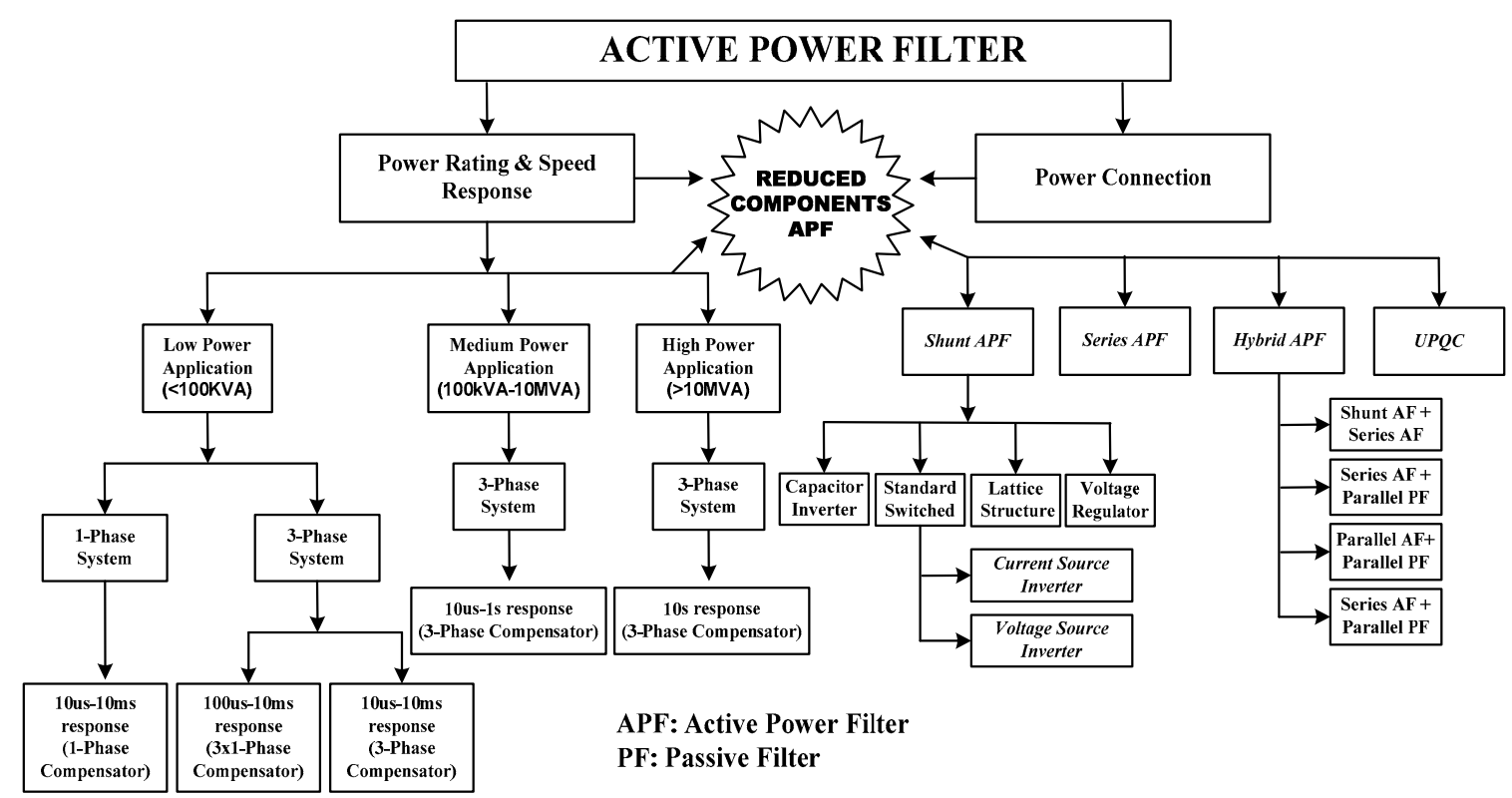

Figure 5. Hierarchical structure of APF classifications.
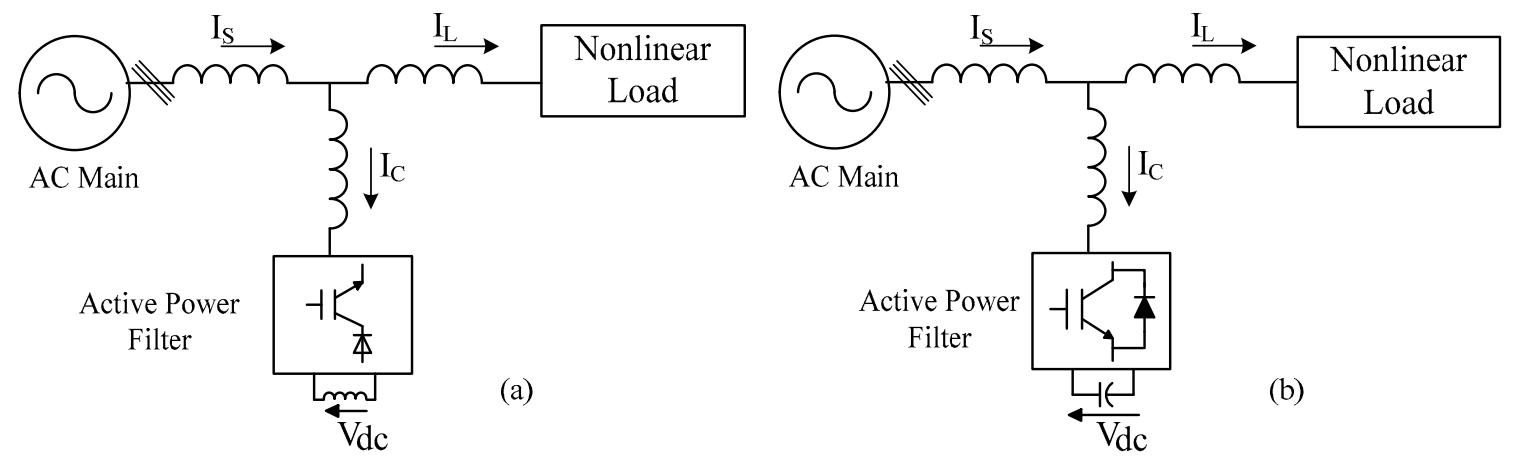

Figure 6. (a) Current-fed- and (b) voltage-fed-type inverters.

The VSI-APF is illustrated in Figure $6 \mathrm{~b}$. This inverter is installed at the load tail in the power network and fed from the energy storage capacitors. This category is more widely used than CSI-APFs and present advantages on PWM-CSI, such as easy installation, simple circuit, low cost, and convertibility to multistep versions with low switching frequencies. These inverters are generally used to eliminate current harmonics, compensate reactive power, and improve imbalanced current. The load phase-type connection is contingents upon three configurations, namely, two- (single phase), three- (three-phase without neutral), and four-wire (three-phase with neutral) configurations [103]. Furthermore, in terms of connections with main power systems, VSIs are divided into three configurations, namely, series, shunt, and arrangements of series and parallel as UPQC [58].

Figure 7a shows series APF topology [104]. The PWM waveform is injected in the system on an instantaneous basis to maintain a pure sinusoidal voltage waveform across the load. A matching transformer is used near the load end to eliminate voltage harmonics. This transformer balances the load terminal voltage and reduces the negative sequence voltage helping in controlling the voltage regulation and harmonic propagation caused by resonance in three-phase electric utilities. This configuration is less used in the industry than other configurations to address the limitation of handling high load currents, high system current ratings, losses, and filter sizes. Table 4 shows 
a critical technical and economic comparison of the power quality improvement techniques found in cited publications regarding shunt APFs [105].

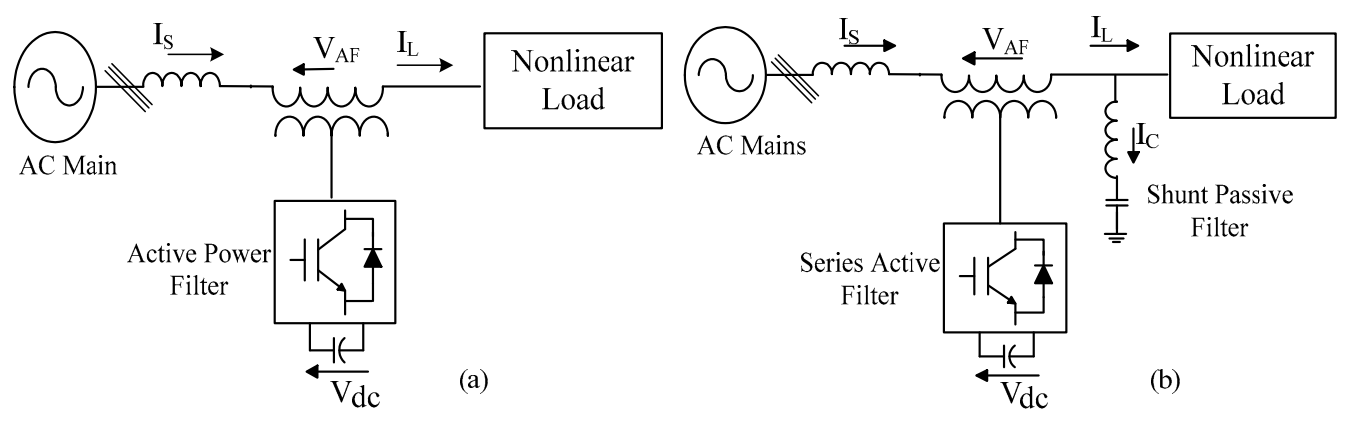

Figure 7. (a) Series and (b) hybrid APFs.

Table 4. Comparison of APFs in terms of power quality improvement techniques.

\begin{tabular}{lccccc}
\hline \multirow{2}{*}{ Attributes } & \multicolumn{5}{c}{ Types of Filter } \\
\cline { 2 - 6 } & Passive Filter & Active Filter & Hybrid Filter & DSTATCOM & UPQC \\
\hline Reactive power compensation & Poor & Good & Good & Excellent & Excellent \\
\hline Harmonic suppression & Fixed & Adjustable & Fixed & Adjustable & Adjustable \\
\hline Resonance & May exist & No & No & No & No \\
\hline Load compensation & Not provided & Not provided & Not provided & Excellent & Good \\
\hline Power rating of power converter & - & High & small & Highest & small \\
\hline Power converter switches & - & 6 & 4,6 & $4,6,12$ & $4,6,8,12,18,24$ \\
\hline Total cost & Lowest & High & Moderate & High & Highest \\
\hline & Cost depends upon the amount of switches. & &
\end{tabular}

\section{Shunt Hybrid APFs}

HAPFs are low-cost systems that compensate harmonic and voltage regulations. Such a system is a combination of passive and active filter devices, as depicted in Figure 5b. HAPFs are arranged into three topology configurations, namely, the combinations of parallel APF with shunt PF, series APF with shunt PF, and APF in series with shunt PF, as shown Figure 8a-c. In the series APF with shunt $\mathrm{PF}$, the active filter is connected across the series to provide high impedance and isolation path for the harmonics to follow in the shunt PF. This configuration is commonly tested in medium-voltage level systems to provide reactive power, voltage harmonic compensation, and three-phase voltage balancing [106].

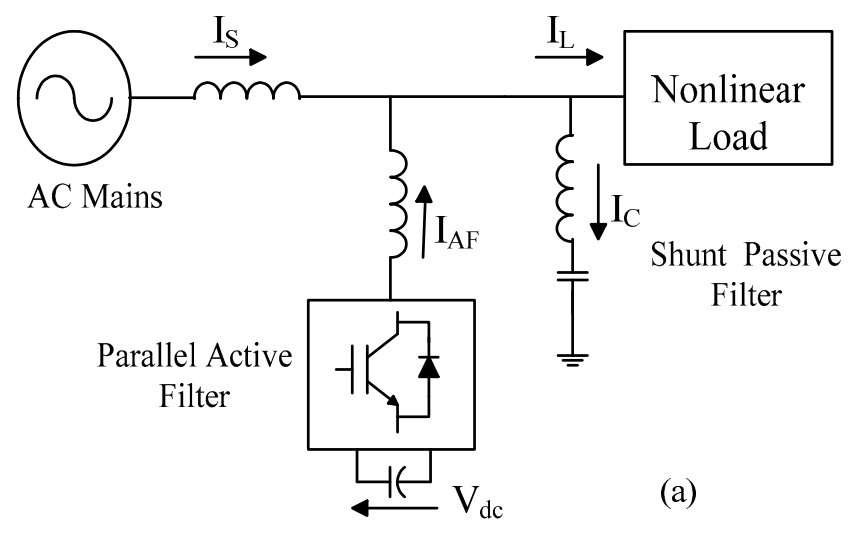

Figure 8. Cont. 

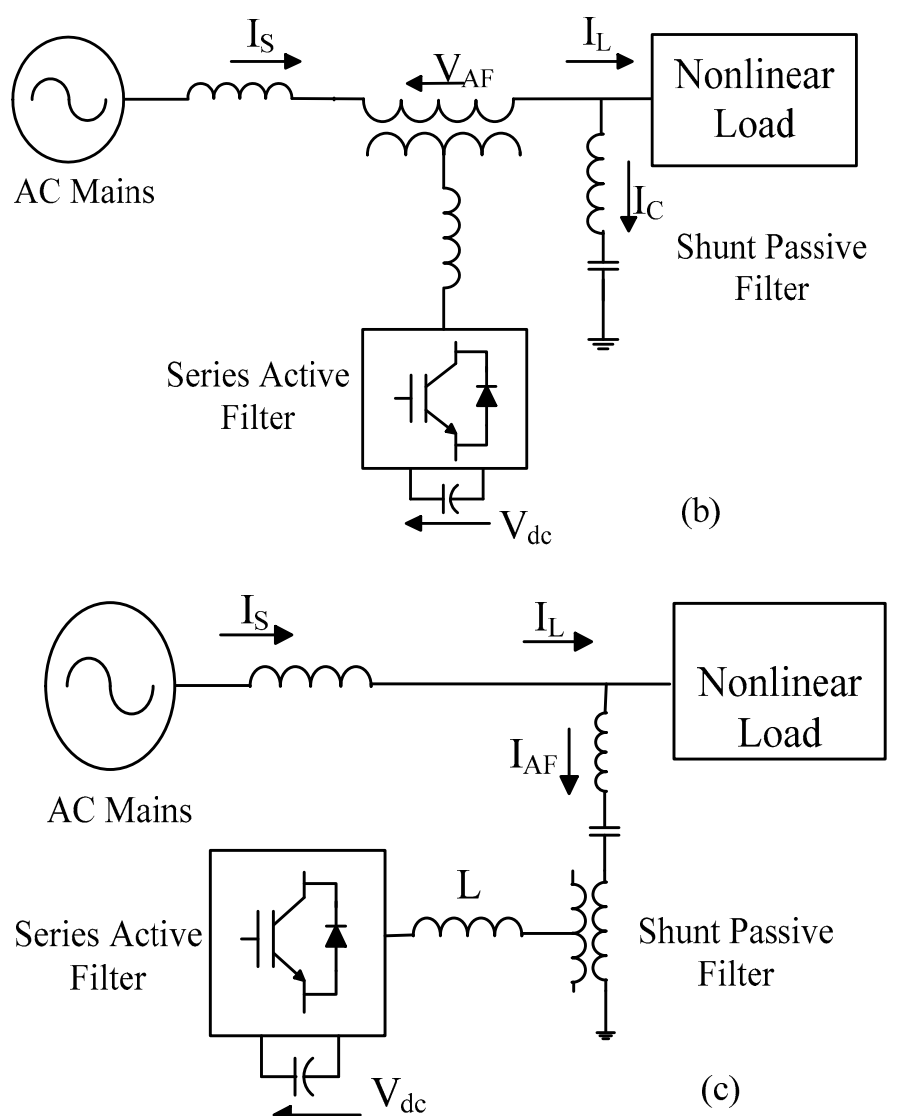

Figure 8. (a) Shunt APF with shunt PF; (b) Series APF with shunt PF; and (c) APF connected in series with shunt PF.

Table 5 summarizes the utilization of shunt APF and HAPF configuration for specific applications [11]. In the shunt APF with shunt PF configuration, both components are connected in shunt position to the main power supply. The shunt APF cancels the low-order current harmonics left by the shunt PF. Both systems are used to eliminate the fundamental reactive power and high-order load current harmonics in high-power systems. Nevertheless, such a system uses a large amount of passive components. Thus, this system is limited to single-load system applications. The series-connected APF with shunt PF is used in medium- and high-voltage applications, in which the DC-link voltage is maintained constant by the APF circuit. Moreover, PFs maintain the fundamental voltage component of the grid to a minimum value to reduce system size, cost, and voltage stress on active switches during filtering [107].

Table 5. Selection of shunt and hybrid APFs for specific applications.

\begin{tabular}{clcccc}
\hline Number & \multicolumn{1}{c}{ Application } & $\begin{array}{c}\text { Teries } \\
\text { Active Filter }\end{array}$ & $\begin{array}{c}\text { Shunt } \\
\text { Active Filter }\end{array}$ & $\begin{array}{c}\text { Hybrid Filter } \\
\text { (Active Series and } \\
\text { Passive Shunt) }\end{array}$ & $\begin{array}{c}\text { Hybrid Filter } \\
\text { (Active Series and } \\
\text { Active Shunt) }\end{array}$ \\
\hline 1 & Voltage harmonic compensation & $*$ & & $*$ & $*$ \\
\hline 2 & Voltage flicker reduction & $*$ & $*$ & $*$ & $*$ \\
\hline 3 & Removing voltage sags & $*$ & $*$ & $*$ & $*$ \\
\hline 4 & Improving voltage regulation & $*$ & $*$ & $*$ & $*$ \\
\hline 5 & Reactive power compensation & & $*$ & $*$ & $*$ \\
\hline 6 & Current harmonic compensation & & $*$ & $*$ & $*$ \\
\hline 7 & Neutral current compensation & & $*$ & $*$ & $*$
\end{tabular}


Table 5. Cont.

\begin{tabular}{clccc}
\hline Number & \multicolumn{1}{c}{ Application } & & Types of Filter \\
\hline 8 & Improving load balancing & & $*$ & \\
\hline 9 & $(1+4)$ & $*$ & & $*$ \\
\hline 10 & $(1+2+3+4)$ & $*$ & $*$ & $*$ \\
\hline 11 & $(1+4+5+6)$ & & $*$ & $*$ \\
\hline 12 & $(1+5)$ & $*$ & $*$ \\
\hline 13 & $(5+6)$ & $*$ & $*$ \\
\hline 14 & $(5+6+7+8)$ & $*$ & $*$ \\
\hline 15 & $(5+6+8)$ & $*$ & \\
\hline 16 & $(6+8)$ & $(5+7+8)$ & $* * *$ indicates the filter system can preform the mention operation.
\end{tabular}

Circuits are further classified into three additional categories on the basis of the number of phase configurations, namely, single-phase two-wire (1P2W), three-phase three-wire (3P3W), and three-phase four-wire $(3 \mathrm{P} 4 \mathrm{~W})$ systems [108]. These circuit categories are applied at high frequency in low-, medium-, and high-power systems, respectively [68,109]. 1P2W filters are further classified as passive-passive [69], passive-active [70], and active-active systems [71,110,111]. Similarly, 3P3W filters are divided into passive-passive [72], passive-active [73], and active-active systems [67]. Finally, 3P4W filters are further classified as passive-passive, passive-active, and active-active systems $[67,112]$. Operating a three-phase power supply in a single-phase load system results in imbalanced neutral current and reactive power load problems. Therefore, many limitations are addressed by the four-wire hybrid configuration. However, the capacitor midpoint switch type is adopted for low-rating applications and the four-leg switch type is for controlling the neutral in the HAPF applications. Some of the practical limitations of shunt APFs are as follows:

- The initial installation cost is high.

- The control structure and design are considerably complex. Moreover, the increased harmonics and losses complicate filter control.

- With rapid dynamic current response and high-power rating system demand, the APF presents a design trade-off.

\section{Advanced Classification of APF/STATCOM}

Cost reduction is an important aspect in designing power converters, particularly in low-power-range industrial applications, such as power filters, variable-speed motor drives, uninterruptible power supplies, and static frequency changers [113]. Table 6 shows the results of testing a reduced number of power converters or inverters for minimizing losses and increasing system feasibility [114-117]. Moreover, the attributes and parameters of different DC-AC inverters are compared. On the basis of the total number of switches or reduced switch count configuration, modified APF inverters are classified as AC-AC power converter, parallel inverter, and split DC-leg inverter topologies. 
Table 6. Comparison of different DC-AC power inverter topologies.

\begin{tabular}{lccll}
\hline \multicolumn{1}{c}{ Topologies } & $\begin{array}{c}\text { Electrical } \\
\text { Isolation }\end{array}$ & $\begin{array}{c}\text { Efficiency } \\
\mathbf{( \% )}\end{array}$ & \multicolumn{1}{c}{ Advantages } & Disadvantages \\
\hline $\begin{array}{l}\text { Single bus inverter with } \\
\text { two paralleled half bridge }\end{array}$ & No & - & -Minimum component count & -Large dc filter components \\
\hline $\begin{array}{l}\text { Dual bus inverter with two split half } \\
\text { bridge single }\end{array}$ & No & - & -Reliability and flexibility & -High component count \\
\hline phase 3 wire inverter & Yes & - & -Small passive component & $\begin{array}{l}\text {-Complex control; for } \\
\text { non-isolated circuit }\end{array}$ \\
\hline Dual phase inverter with transformer & Yes & - & -Boosting capability & -Higher cost and size \\
\hline Three-phase PWM inverter & Yes & $\sim 98 \%$ & -Simple design and control & - \\
\hline $\begin{array}{l}\text { High frequency link inverter } \\
\text { Z source inverter }\end{array}$ & Yes & $\sim 96 \%$ & -Boosting capability & $\begin{array}{l}\text {-Highly complex; higher cost } \\
\text { and size }\end{array}$ \\
\hline $\begin{array}{l}\text { LLCC resonant inverter } \\
\text { No }\end{array}$ & $\sim 98 \%$ & $\begin{array}{l}\text {-Boosting capability; save } \\
\text { cost, no need for extra } \\
\text { dc/dc converter }\end{array}$ & $\begin{array}{l}\text {-Complex control; current } \\
\text { stress is high }\end{array}$ \\
\hline
\end{tabular}

\subsection{AC-AC Power Converter Topology}

Figure 9a illustrates the system configuration of 3P3W AC-AC APF power converter topology that is connected with the distribution network and three-phase nonlinear harmonic-producing loads. The H-bridge converter circuit, represented by " $\mathrm{H}$ " is connected with a single DC-link capacitor $\left(C_{d c}\right)[118,119]$. This circuit consumes different numbers of switches installed in series and shunt and hybrid combinations of SAPF systems. The compensating current is injected into the AC distribution network at the PCC by coupling AC inductors or transformers [120]. The 3P3W AC-AC APF-VSI configuration consists of six and nine semiconductor devices, compared with the twelve switches in the conventional circuit [121-123]. The H-type APF topology, together with the DC-link capacitor, successfully reduces heavy switching power loss and minimizes voltage stress on active switches. However, this topology exhibits drawbacks in the form of DC-link voltage imbalance and minimum adept DC-link voltage [124].

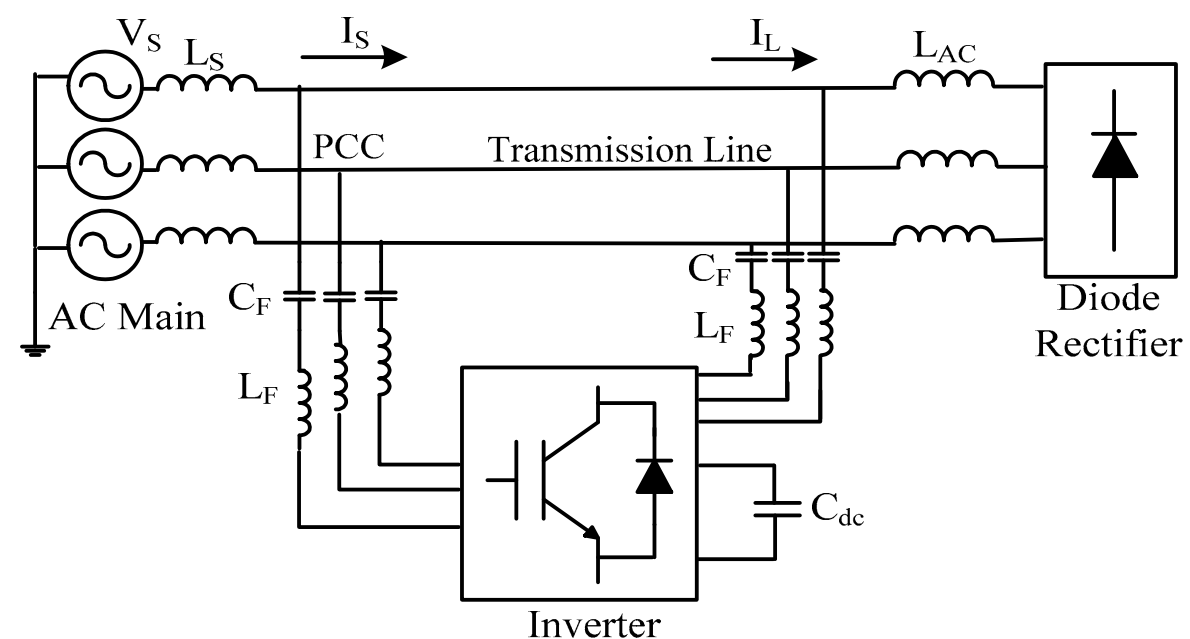

(a)

Figure 9. Cont. 


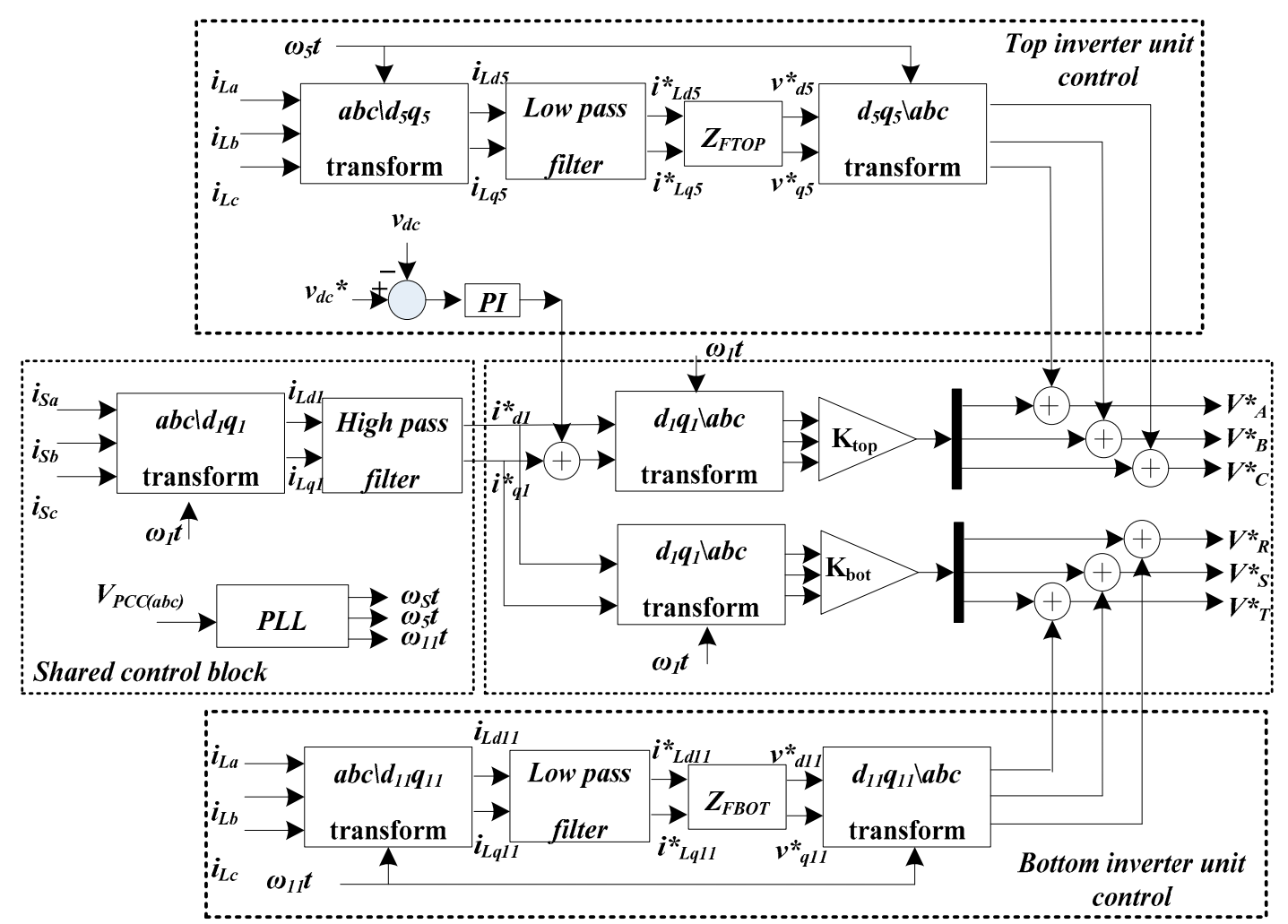

(b)

Figure 9. (a) AC-AC inverter topology and (b) control block of the proposed hybrid power filter based on SSTL inverter.

A six-switch inverter circuit, which consists of a two-leg inverter coupled with a single DC-link capacitor, is presented [125]. The number of semiconductor devices is reduced from a two-leg nine-switch inverter to a low-cost two-leg six-switch inverter circuit. The six- and nine-switch APF-VSI is connected in series with two passive LC filters in shunt position to the AC power transmission line without installing any matching transformer. The improved compact circuit design displays higher compensation results than the conventional 3P3W APF-VSI. A combination of feedback and feed-forward control loops is adopted as an advanced control scheme [126,127]. Figure $9 \mathrm{~b}$ illustrates the control block diagram, which controls each unit and consists of three subsystems [128], which are a top and a bottom inverter unit and a shared control unit. Each PF is tuned at different harmonic frequencies to mitigate the 5th and 7th harmonics at the top inverter and the 11th and 13th harmonics at the bottom inverter. This PF also maintains the balance of DC-link voltage compensation. To reduce the DC-link current through the DC side of the system, a capacitor is installed between the DC-link poles and the PCC [129]. However, the shared control unit operates with PLL scheme, which consists of a simple and robust voltage pre-filter. This unit generates a quasi-square wave, thereby proving its advanced compensation and harmonic contents compared with those of conventional APF systems. Additionally, the $\mathrm{H}$-bridge modular structure type reduces manufacturing cost and presents rapid production rate and high reliability. The controller should track a single capacitor voltage, thereby reducing the complexity of the voltage regulation, and requires additional voltage sensors in terms of multilevel inverter configurations [130,131].

\subsection{Parallel-Inverter APF Topology}

A dual-hybrid converter stage or parallel-inverter topology is depicted in Figure 10 [132]. In this topology, the rectifier and inverter are coupled with a parallel DC-link storage device in 
the APF topology but maintains a large number of switching devices. The conventional coupled back-to-back H-bridge inverter is a well-established, low-voltage configuration used in many industrial applications [133,134]. This inverter usually consists of twelve switches. On the contrary, the improved configuration eliminates four switches from each inverter, thereby reducing the total number of switches to eight; the scheme is adopted to eliminate a single leg in each power converter by connecting the third phase to the negative terminal of the individual VSI [135]. The new configuration increases system reliability and decreases voltage stress across the active switches.

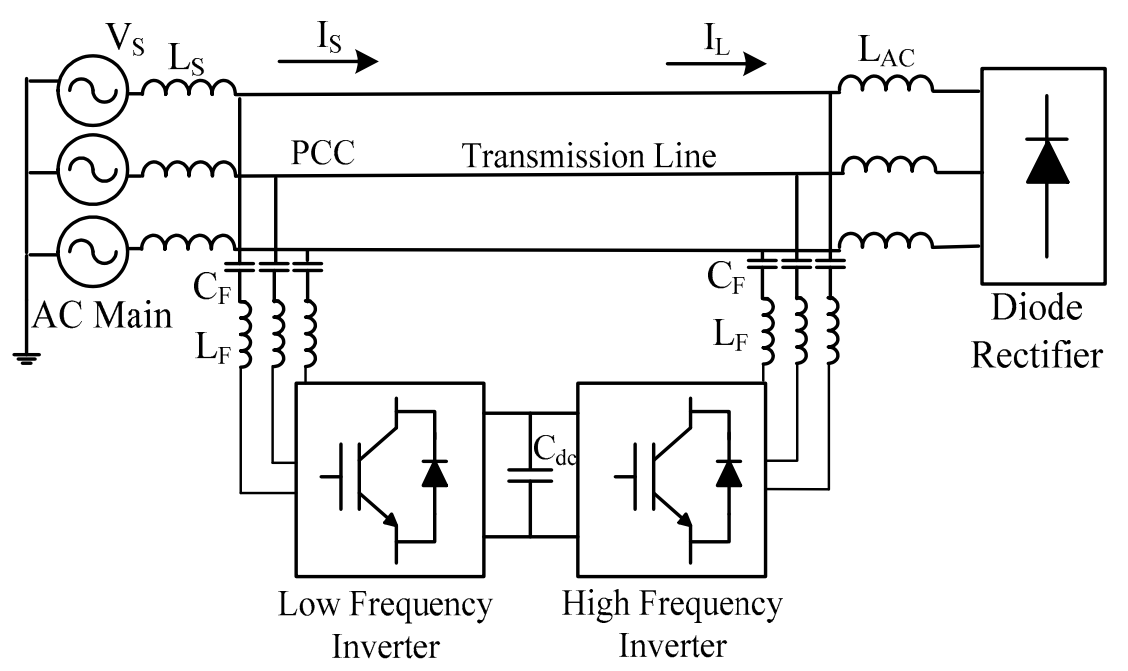

Figure 10. Parallel inverter topology.

A large-value DC capacitor is needed for stabilizing voltage balance across the DC-link capacitors and producing reactive power in high-power dynamic load systems. However, the DC-side energy storage component is the main limitation contributing to circuit failure. The DC energy storage components shorten the lifespan of the converter [136]. In addition, these components are expensive and largely fail in a power electronic circuit. Many factors, such as dissipation of heat, degradation of energy parameter, and high value of voltage capability, contribute to the high failure rate. The DC energy storage component is arranged in the aluminum electrolytic capacitors, which act as filters and energy buffers to the AC voltage ripples in the APF system. The aging of the aluminum electrolytic capacitors increases its internal resistance and contributes the most to frequent damage in operation [137]. In addition, these capacitors are expensive, large, and heavy and primarily cause power converter failure.

Switch reduction leads to a complex control and structure design for stopping the flow of zero-sequence current that circulate between the two power converters. Hence, the most suitable solution is installing a transformer or isolating the DC capacitors [135]. The parallel inverter topology presents limitations in the form of an oversized DC-link capacitor, restricted amplitude sharing, and limited phase shift at the output terminals. To overcome the issue of switching losses and electromagnetic interferences due to high switching frequency, soft switching techniques, such as zero-voltage transition and zero-current transition schemes, are adopted [138]. A control technique is implemented on the basis of feed-forward and feedback loops, as shown in Figure $9 \mathrm{~b}$. The low-frequency inverter (LFI), tuned at $550 \mathrm{~Hz}$, mitigates low-order harmonics, and maintains the DC-link voltage and reactive power demand on the system constant. In the arrangement, the high-frequency inverter (HFI), tuned at $750 \mathrm{~Hz}$, eliminates the remaining high-level harmonics. The control block functions in two loop modes, namely, feed-forward loop, which controls the LFI and improves the dynamic response from the system, and feedback loop, which operates the HFI and obtains high steady-state and harmonic compensation results. The Clarke and Park transformation technique is adopted to determine the cosine and sine components. The synchronous 
reference frame (SRF) method is used to generate the reference current for the parallel APF inverter topology [139]. Table 7 compares mainstream power converter topologies according to different topology parameters [140,141].

Table 7. Comparison of mainstream power converter topologies.

\begin{tabular}{clccccccc}
\hline Series & \multicolumn{1}{c}{$\begin{array}{c}\text { Converter } \\
\text { Topology Features }\end{array}$} & $\begin{array}{c}\text { Diode } \\
\text { Rectifier }\end{array}$ & $\begin{array}{c}\text { 2L-B2B } \\
\text { VSC }\end{array}$ & ZSI & $\begin{array}{c}\text { Multi-Level } \\
\text { Converter }\end{array}$ & $\begin{array}{c}\text { Matrix } \\
\text { Converter }\end{array}$ & $\begin{array}{c}\text { Nine Switch } \\
\text { AC-AC } \\
\text { Converter }\end{array}$ \\
\hline 1 & Need controlled switches & None & Less & Less & Large & Large & Least \\
\hline 2 & Circuit configuration & Simple & Simple & Simple & Complex & Complex & Simple \\
\hline 3 & Cost & Very low & Moderate & High & Very high & high & Low \\
\hline 4 & DC-link capacitor & Yes & Yes & Yes & Yes & No & Yes \\
\hline 5 & Operational stages & Two & Two & Two & Two & One & One \\
\hline 6 & Waveform quality & Good & Better & Better & Best & Better & Depends \\
\hline 7 & Harmonic distortion & High & Moderate & Low & Least & Low & Depends \\
\hline 8 & Switches losses & None & High & High & Low & Low & High \\
\hline 9 & Conduction losses & Low & Low & Low & Highest & High & Low \\
\hline 10 & Reliability & High & Low & High & Low & High & Low \\
\hline 11 & Bi-directional power flow & No & Yes & Yes & Yes & Yes & Yes \\
\hline 12 & Control complexity & Easy & Moderate & Moderate & $\begin{array}{c}\text { Most } \\
\text { complex }\end{array}$ & More & complex & complex \\
\hline
\end{tabular}

\subsection{Split DC-Leg Inverter Topology}

Split DC-link topology provides a neutral common point for three-phase VSI, 3P3W, and 3P4W systems [142,143], and uses two connector pairs to split the single leg, thus providing a neutral path or midpoint connection [144,145], as depicted in Figure 11. The three-leg split capacitor and four-leg VSI-based topologies are the most demanding configurations for the 3P3W APF system. However, the two-level VSI configuration is inappropriate for filtering and harmonic compensation in high-power applications. The four-switch (B4) inverter uses four switches and four diodes, unlike the practical six-switch inverter (B6) [146]. Split DC-link topology uses few semiconductor devices, a feature that helps the neutral current, which consists of a small fundamental value of AC components. Table 8 compares the performance of the split DC-leg APF with the conventional APF topologies [147].

Table 8. Performance comparison of split DC-leg APF with conventional APF topologies.

\begin{tabular}{llll}
\hline \multicolumn{1}{c}{ Split DC-Link topology } & \multicolumn{1}{c}{ Conventional Topology } \\
\hline \multicolumn{1}{c}{ Advantages } & \multicolumn{1}{c}{ Disadvantages } & Advantages & Disadvantages \\
\hline Simple design & $\begin{array}{l}\text { Unequal voltage sharing in } \\
\text { between the split } \\
\text { capacitors legs }\end{array}$ & $\begin{array}{l}\text { Handle unbalanced and } \\
\text { nonlinear conditions }\end{array}$ & $\begin{array}{l}\text { Need two or many } \\
\text { extra switches }\end{array}$ \\
\hline Fewer converter switches & Need an expensive capacitors & Low DC-bus voltage & $\begin{array}{l}\text { Complicated } \\
\text { control strategy }\end{array}$ \\
\hline $\begin{array}{l}\text { Simple and fast current } \\
\text { tracking control }\end{array}$ & $\begin{array}{l}\text { Unbalanced and nonlinear } \\
\text { loads reason a split } \\
\text { voltages perturbation }\end{array}$ & $\begin{array}{l}\text { AC output voltage can } \\
\text { be greater (about \%15) } \\
\text { than the output of split } \\
\text { DC-link topology }\end{array}$ & - \\
\hline - & $\begin{array}{l}\text { Need a neutral point } \\
\text { balancing technique }\end{array}$ & $\begin{array}{l}\text { Lower ripple in the } \\
\text { DC-link voltage }\end{array}$ \\
\hline
\end{tabular}




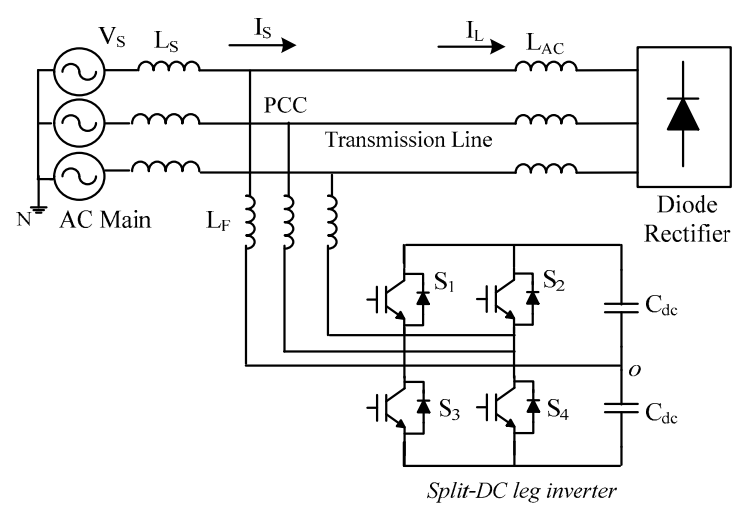

Figure 11. Four-switch DC-split voltage source inverter topology.

The drawback of split DC-link topology is its need for an expensive and large capacitor value to achieve equal voltage sharing between split capacitors [148]. Under severe imbalanced and nonlinear conditions, a large amount of neutral current flows through the neutral path, thus causing perturbation in the control scheme. However, due to its circuitry, split DC-link topology utilizes less expensive capacitors to provide a maximum available line-line peak voltage $\left(V_{d c} / 2\right)$ and maintain a low-ripple DC-link voltage. The dual-bridge inverter practices the $\mathrm{B} 4$ technique and eliminates variations in the current and voltage of DC-link capacitors. In 3P4W inverters, the AC voltage is 15\% higher than in split DC-link inverters [149,150]. Hence, the three phase four-leg (3P4L) inverter shows superior performance under imbalanced and nonlinear conditions at the cost of a complicated control scheme. PWM or space vector modulation (SVM) techniques are adopted to generate reference signals for the PWM inverter. An overview of advanced core technologies for the power quality systems of high-power electronics is illustrated in Figure 12 [88,139].

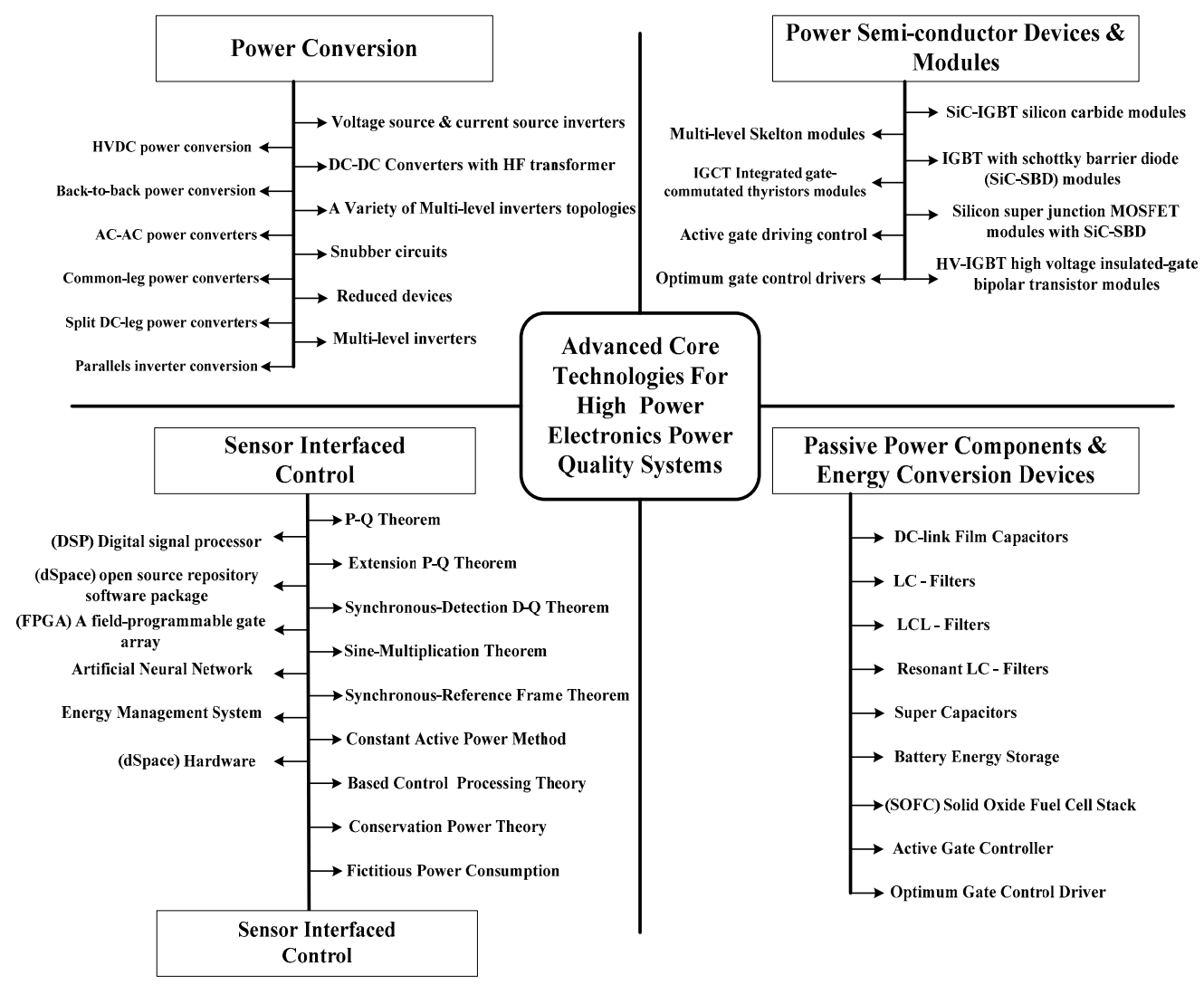

Figure 12. Overview of advanced core technologies for power quality systems of high-power electronics. 


\section{APFs/STATCOM Control Techniques}

The primary operation of power converters depends on the control modulation strategies for controlling parameters such as switching losses, THD of the output current or voltage, amplitude, frequency and phase synchronization, sudden dynamic response, and power factor correction [151]. Generally, APF control is divided into two sections [152], specifically, reference signal estimation technique. As depicted in Figure 13, reference signal estimation is further classified into two sub-categories: current or voltage reference synthesis and current or voltage reference calculation [153].

Control signal techniques are sub-categorized further into two domains, namely, frequency-domain and time-domain as shown in Figure 13. However, depending upon open- and closed-loop concepts, closed-loop control is sub-classified into constant inductor current, constant capacitor voltage, linear voltage control, and optimization techniques [154]. These techniques are further arranged into modern control techniques for output voltage control, current regulation, harmonic filtering, and compensation in all critical circumstances $[155,156]$.

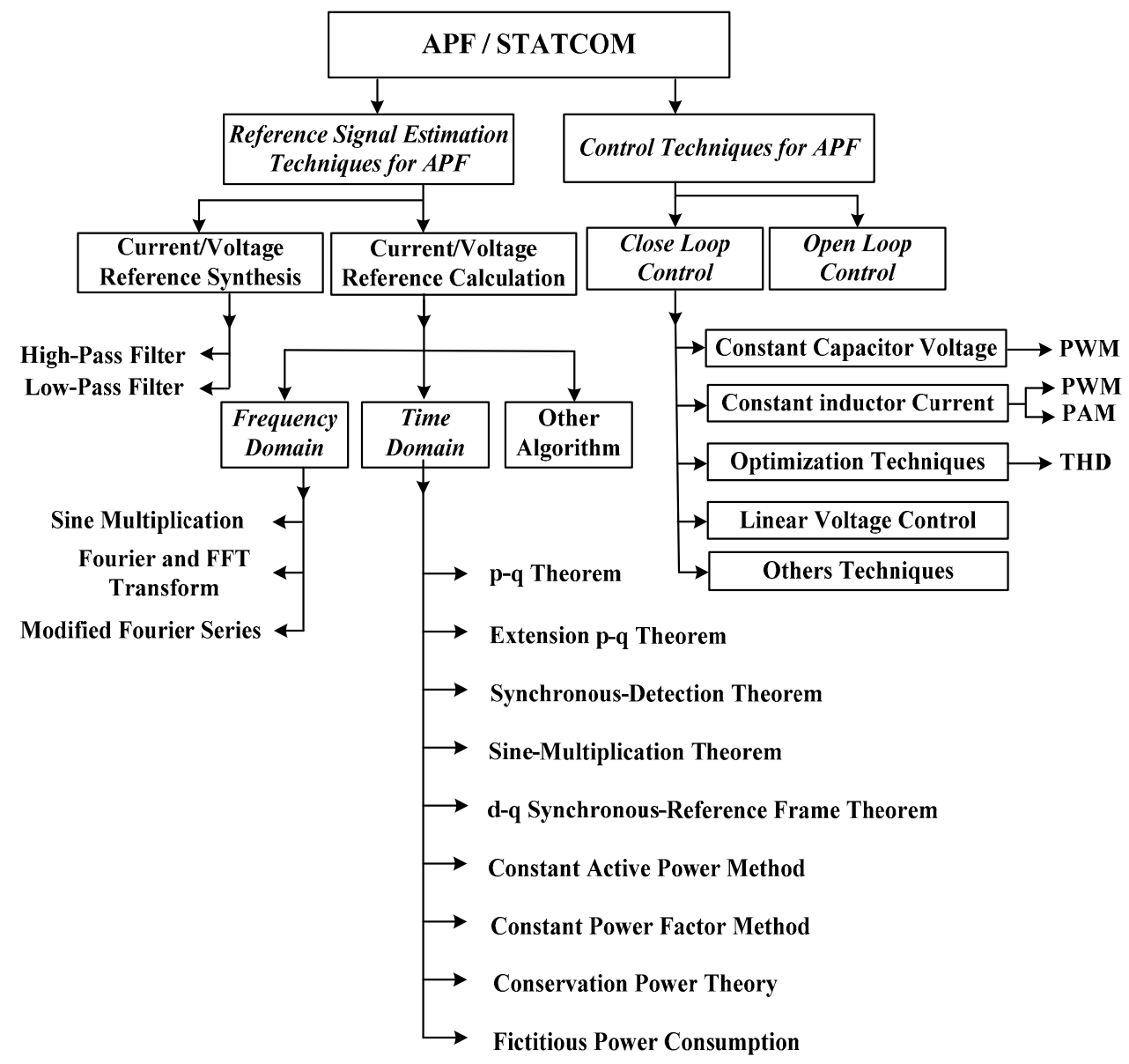

Figure 13. Different control techniques.

Frequency-domain techniques are more accurate and efficient than time-domain approaches for generating certain reference signals. Techniques such as Fourier transform analysis [157], sine multiplication technique [158], and modified Fourier series technique [159] estimate the existing harmonics in the system and generate reference signal in response to the present harmonics. However, compared with time-domain techniques, frequency-domain techniques are limited by their need for complex control circuitry. Moreover, these techniques require more time (one cycle) than time-domain methods to calculate Fourier coefficients, reference currents, and voltage signals for the sampling of variable coefficients. Meanwhile, time-domain techniques use instantaneous $p-q$ theory [160], 
synchronous $d-q$ reference frame theorem [161], synchronous detection theorem [120,162], constant power factor algorithm [163], PI controller [156], fuzzy controller [164], hysteresis controller [165], and sliding-mode controller [166]. Methods such as dividing frequency control [167] and extension $p-q$ theorem [168] are implemented to generate the reference signals, which implement the $p-q$ technique. Similarly, the synchronous $d-q$ reference, known as SRF, practices the notch filter method [169] for calculating the voltage and current reference for the synchronously rotating reference frame, as in the case of the DC bus feedback voltage-fed APFs. Besides these control methods, other controllers are widely practiced in the operation of APF systems, including indirect current and adaptive DC-link control [47], PWM control [170,171], sine wave triangle PWM [172], deadbeat control [173], adaptive fuzzy dividing frequency controller [174], synchronous flux detection algorithm [175], neural network [176] and reactive current extraction [177].

\section{Advanced Control Techniques for APFs/STATCOM}

The reduction of switching components in any system leads to certain limitations. To overcome these, two advanced control techniques are adopted for operating the reduced switch count inverter, namely, SPWM and SVPWM, which operate in open- and closed-loop strategies, respectively. SVM is more complex than SPWM in optimizing control; switching schemes are selected according to the appropriate designs of the inverter and the topology [178]. This section provides a detailed review of the two advanced modulation methods and compares their advantages and limitations in matching the reduced switch count inverter topologies [171].

\subsection{Sinusoidal Pulse Width Modulation}

SPWM is one of the standard modulation techniques in switching power converters [179]. To control the gate switching signal for inverter operations, a low-frequency sinusoidal reference signal as comparator is compared with a high-frequency triangular carrier signal. The comparator output defines the operating range of switching orders. In addition, the key factor to consider in modulator design is amplitude distortion, which is caused by variations in the DC-voltage source. To control the desired line voltage frequency, the frequency of the modulating sinusoidal signal defines the inverter output. The amplitude distortion of the PWM waveforms stops the amplitude of the fundamental component and produces low-order harmonic contents [180]. However, THD and power dissipation are two of the key issues in high-power converter applications. Thus, a fundamental frequency SPWM control method is adopted to minimize switching losses and optimize harmonic contents. The SPWM modulation scheme can easily be implemented for single- and multiple-carrier applications. Multicarrier SPWM control techniques increase the performance of high-level inverters.

Sinusoidal SPWM is the most enhanced technique in PWM [181] and offers the key benefits of easy execution, low THD and harmonic output, and low switching losses. Similar to the six-switch converter, the SPWM is implemented in a reduced four-switch configuration. The comparators and the carrier signals are similar to those in the conventional SPWM; the only difference lies in the command to control the reference signal pattern for controlling the four-switch power converter. Reduced switch count inverters are not symmetrical; thus, the phase shift between the reference signals changes to compensate for the DC-bus voltage fluctuations [182]. Moreover, minimal single-phase current passes through DC-link capacitors but at the cost of complex control strategies and additional hardware. Phase voltages are preferred for the power converter presented in Figure 12, as discussed below:

$$
\begin{gathered}
v_{a}=V_{m} \sin (\omega t) \\
v_{b}=V_{m} \sin \left(\omega t-\frac{2 \pi}{3}\right) \\
v_{c}=V_{m} \sin \left(\omega t+\frac{2 \pi}{3}\right)
\end{gathered}
$$


When the third-leg phase of the VSI has no control, the middle connection point of the DC-link (point $\mathrm{O}$ ) is taken as the reference (as demonstrated in Figure 11).Therefore:

$$
\begin{gathered}
v_{a n}=V_{a}-V_{c}=\sqrt{3} V_{m} \sin \left(\omega t-\frac{2 \pi}{6}\right) \\
v_{b n}=V_{b}-V_{c}=\sqrt{3} V_{m} \sin \left(\omega t-\frac{2 \pi}{2}\right) \\
v_{c n}=V_{c}-V_{c}=0
\end{gathered}
$$

The infinite value of the modulation bandwidth of periodic signal produces harmonics. Theoretically, these harmonics are neglected in SPWM control; however, the harmonics in the carrier and data modulation signal are filtered out by digital filters, such as Butterworth, Chebyshev, Bessel, Elliptic, and ITEA, which minimize the time integral and enhance the filtering functions to eliminate carrier signal harmonics [183].

\subsection{Space Vector Pulse Width Modulation}

SVPWM is an enhanced control method for reduced switch count inverters and directly uses the system parameters to determine the correct switching states and identify each switching vector $[184,185]$. SVPVM determines the duty cycle according to the modulation scheme. The switching vectors are divided into six sectors in the complex space plane of $(a, b)$. All the sectors are separated by combining the turn-on and turn-off switching states of the power inverter. However, the lookup table and sector identification make SVM a complex scheme for determining the switching intervals for all vectors. The two adjacent switching state vectors are identified by the reference vectors. These vectors compute the turn-on and turn-off states of each switch; the sectors or subsectors find the switching sequences and increase the $\mathrm{n}$-level of the power inverter, which requires a microprocessor and complex algorithms. The limitation of SVM is that it needs a considerable amount of time to carry out fundamental calculations, thereby causing delays in the process [186]. To overcome this problem, a large value of system reactive components and advanced deadbeat control are used [187]. The fundamental voltage ratios and harmonic compensation show better results in SVM schemes than in SPWM. Furthermore, SPWM also has a peak output voltage that is $15 \%$ higher than triangular carrier signal-type modulation techniques [188].

Generally, the SVM scheme is used in multilevel power inverter systems and employs a maximum number of different-level carrier waves to compare with the reference voltage signals, thus generating the n-level space vector that consists of per-sector and n-switching states for positive, zero, and negative switching sequences $[189,190]$. These vectors are divided among three groups, namely, small, middle, and large value vectors. Furthermore, the reference voltage depends on the voltage vectors and its dwelling times during the sampling period $\left(T_{S}\right)$ for the output voltage. The switching status and the pole voltages are determined by the switching status and can be calculated as follows:

$$
\begin{aligned}
V_{N Z} & =\frac{1}{3}\left(V_{A Z}+V_{B Z}+V_{C Z}\right) \\
v_{a} & =V_{A N}=V_{A Z}-V_{N Z} \\
v_{a} & =V_{B N}=V_{B Z}-V_{N Z} \\
v_{a} & =V_{C N}=V_{C Z}-V_{N Z}
\end{aligned}
$$

The combinations of the two-leg four-switch $\left(S_{1}-S_{4}\right)$ converters result in four space vectors. Expression (11) is used to calculate the vector representation of the three phase variables:

$$
\left[\begin{array}{l}
x_{\alpha} \\
x_{\beta}
\end{array}\right]=\frac{2}{3}\left[\begin{array}{ccc}
1 & -\frac{1}{2} & -\frac{1}{2} \\
0 & \frac{\sqrt{3}}{2} & -\frac{\sqrt{3}}{2}
\end{array}\right]\left[\begin{array}{l}
x_{a} \\
x_{b} \\
x_{c}
\end{array}\right]
$$


Note that the B4 converter does not have zero vectors, unlike the B6 converter. Based on the calculation of the remaining active vectors, the three pole voltages do not have the same potential during the operation. To calculate the sectors, the volt-second integral is expressed in Expression (12):

$$
\vec{V} T_{s w}=\vec{V}_{1} t_{1}+\vec{V}_{2} t_{2}+\vec{V}_{3} t_{3}+\vec{V}_{4} t_{4}
$$

The vector decomposition of the above equation along with the time weights restriction can be written as:

$$
\begin{gathered}
\vec{V} T_{s w} \cos \varphi=-V_{1} t_{1} \cos \frac{\pi}{3}+V_{2} t_{2} \cos \frac{\pi}{6}+V_{3} t_{3} \cos \frac{\pi}{3} \\
\vec{V} T_{s w} \sin \varphi=-V_{1} t_{1} \sin \frac{\pi}{3}-V_{2} t_{2} \sin \frac{\pi}{6}-V_{3} t_{3} \sin \frac{\pi}{3} \\
T_{s w}=t_{1}+t_{2}+t_{3}
\end{gathered}
$$

The modulation time is calculated by solving Expression (13) as follows:

$$
\begin{gathered}
t_{2}=\frac{\sqrt{2} V T_{S W}}{2} \cos \left(\varphi-\frac{\pi}{6}\right) \\
t_{1}=-t_{2}+T_{S W}\left(\frac{1}{2}-\frac{\sqrt{2} V \sin (\varphi)}{E}\right) \\
t_{3}=T_{S W}-t_{1}-t_{2}
\end{gathered}
$$

The calculated vectors choose the sequence for SVM modulation with high symmetry and low switching frequency, as explained in study of [191,192]. Table 9 summarizes the evaluation of harmonic detection methods for APF systems and power grid-tied practical applications [193].

\section{Performance Evaluation of APF/STATCOM System}

A filtering system is needed to analyze the performance of APF/STATCOM applications under nonlinear load conditions. In the evaluation process, several features are important to calculate the performance of the APF system, such as THD of output current and voltage, transient and steady-state response, reactive power compensation and in some cases unity input power factor. The model specification and performance of the filter are evaluated in accordance with standards such as IEEE 519 . The system consists of six active IGBT module inverters with a DC-link capacitor installed in the shunt position with the power grid system. All the experimental parameters and results are explain in the study [194], where a $2 \mathrm{kVA}$ laboratory prototype test-rig is tested with the $5 \mathrm{~kW}$ three-phase diode rectifier load. The utility voltage, load current, and utility current waveforms of the system are seriously distorted and non-sinusoidal, thereby showing the nonlinear diode rectifier load as having a THD of $39.48 \%$. According to the IEEE standard 519, the minimum THD value in utility current harmonics should be less than $5 \%$ and the preferred input unity power factor should not be less than 0.8 . As explain in the study, all the waveforms are nearly sinusoidal after compensation and the THD of the utility current is reduced to $4.2 \%$, with an output voltage THD of $3 \%$. However, the rated DC-link capacitor is selected to keep the voltage ripple under $1 \%$ and maintain a DC voltage of $300 \mathrm{~V}$, which is sufficient for proper and effective APF/STATCOM operation. To demonstrate the response time against the sudden changes in nonlinear load, the system is tested during the step load changes (step-on and step-off operations). The response time of the prototype is fast, achieving excellent performance during the load change ( 0 to $100 \%$ ), and vice versa. Table 10 summarizes the market review of the available STATCOM, SVC and APF products for low and high power applications [195-201]. Traditionally, different manufacture sizes of STATCOM, SVC and APF devices are used to fulfil the power grid requirement [202-205]. 
Table 9. Evaluation of harmonic detection methods.

\begin{tabular}{|c|c|c|c|c|c|c|c|}
\hline Parameters & $\begin{array}{l}\text { Fast Fourier } \\
\text { Transform FFT }\end{array}$ & $\begin{array}{l}\text { Discrete Fourier } \\
\text { Transform DFT }\end{array}$ & $\begin{array}{c}\text { Recursive } \\
\text { Discrete Fourier } \\
\text { Transform RDFT }\end{array}$ & $\begin{array}{l}\text { Synchronous } \\
\text { Fundamental } \\
\text { DQ Frame }\end{array}$ & $\begin{array}{c}\text { Synchronous } \\
\text { Individual Harmonic } \\
\text { DQ Frame }\end{array}$ & $\begin{array}{l}\text { Instantaneous } \\
\text { Power PQ Theory }\end{array}$ & $\begin{array}{l}\text { Generalized } \\
\text { Integrators }\end{array}$ \\
\hline $\begin{array}{l}\text { Number of Sensors (For a Case } \\
\text { of Three-Phase Application) }\end{array}$ & Three currents & Three currents & Three currents & $\begin{array}{l}\text { Three currents, } \\
\text { two/three voltages }\end{array}$ & $\begin{array}{l}\text { Three currents, } \\
\text { two/three voltages }\end{array}$ & $\begin{array}{l}\text { Three currents, } \\
\text { three voltages }\end{array}$ & Three currents \\
\hline $\begin{array}{l}\text { Number of Numerical Filters } \\
\text { Required by the Harmonic } \\
\text { Detection Algorithm }\end{array}$ & 0 & 0 & 0 & $2 \times \mathrm{HPFs}$ & $2 \times$ LPFs $\times N^{*}$ & $2 \times \mathrm{HPFs}$ & $2 \times N^{*}$ \\
\hline $\begin{array}{l}\text { Additional Tasks Required by } \\
\text { the Harmonic } \\
\text { Detection Algorithm }\end{array}$ & $\begin{array}{l}\text { Windowing, } \\
\text { synchronization }\end{array}$ & $\begin{array}{l}\text { Windowing, } \\
\text { synchronization }\end{array}$ & & PLL & PLL & $\begin{array}{c}\text { Voltage } \\
\text { Preprocessing }\end{array}$ & . \\
\hline $\begin{array}{l}\text { Calculation Burden (Excluding } \\
\text { the Numerical Filters) }\end{array}$ & - & - & + & + & - & + & - \\
\hline $\begin{array}{l}\text { Numerical } \\
\text { Implementation Issues }\end{array}$ & $\begin{array}{l}\text { Calculation } \\
\text { Burden, }\end{array}$ & Calculation Burden, & $\begin{array}{l}\text { Instability for } \\
\text { low precision }\end{array}$ & Filtering & Filtering, Tuning & Filtering & Tuning control \\
\hline $\begin{array}{l}\text { Related Algorithms } \\
\text { or Implementations }\end{array}$ & $\begin{array}{l}\text { Similar FFT } \\
\text { algorithms }\end{array}$ & . & Rotating frame & Filter type & Filter type & $\begin{array}{l}\text { Filter type; other } \\
\text { theoriespqr,pq0 }\end{array}$ & $\begin{array}{l}\text { Resonant } \\
\text { filters type }\end{array}$ \\
\hline $\begin{array}{l}\text { Applications in Single- or } \\
\text { Three-Phase Systems }\end{array}$ & Both1-ph/3-ph & Both1-ph/3-ph & Both1-ph/3-ph & Inherently 3-ph & Inherently 3-ph & Inherently 3-ph & Both 1-ph/3-ph \\
\hline $\begin{array}{l}\text { Usage of the Voltage } \\
\text { Information in the Algorithm }\end{array}$ & No & No & No & Yes & Yes & Yes & No \\
\hline $\begin{array}{l}\text { Method's Performance for } \\
\text { Unbalanced and Pre distorted } \\
\text { Line Voltages }\end{array}$ & ++ & ++ & ++ & + & + & - & ++ \\
\hline $\begin{array}{l}\text { Method's Performance for } \\
\text { Unbalanced Load Currents }\end{array}$ & ++ & ++ & ++ & + & ++ & ++ & + \\
\hline $\begin{array}{l}\text { Applied for Selective } \\
\text { Harmonic Compensation }\end{array}$ & No & Yes & Yes & No & Yes & No & Yes \\
\hline Transient Response Time & - & - & + & ++ & + & ++ & + \\
\hline Steady-State Accuracy & + & + & + & - & + & + & - \\
\hline
\end{tabular}

"+" indicates an increase in performance; " -" indicates a decrease in performance. 
Table 10. STATCOMs, SVCs and APFs technology products for high power applications available in the market.

\begin{tabular}{|c|c|c|c|}
\hline \multicolumn{4}{|c|}{ Available Sizes of STATCOM } \\
\hline Company & Product Name/Types & Voltage Level & Single Unit Capacity \\
\hline ABB & PCS 6000 STATCOM & $\begin{array}{l}\text { Several-Typical } \\
(11,20,21,33,138) \mathrm{KV}\end{array}$ & $(6 \ldots \ldots . .16)$ MVAR \\
\hline HITACHI & STATCOM & $(66) \mathrm{KV}$ & (20) MVAR \\
\hline $\begin{array}{l}\text { DONGFANG HITACHI (CD) } \\
\text { ELECTRIC CONTROL } \\
\text { EQUIPMENTS CO., LTD. }\end{array}$ & DHSTATCOM & (6) KV & $(600 \ldots \ldots . . .46000)$ KVAR \\
\hline $\begin{array}{l}\text { CONDENSATOR } \\
\text { DOMINIT GMBH }\end{array}$ & $\begin{array}{l}\text { KLARA-S, KLARA-M, } \\
\text { KLARA-I }\end{array}$ & $\begin{array}{l}\text { Several-Typical } \\
(400 / 525 / 690) \mathrm{V}\end{array}$ & $(5 / 10,6 / 12,12 / 25)$ KVAR \\
\hline GAMESA ELECTRIC & STATCOM & $(11,8 \ldots . .34,5) \mathrm{KV}$ & $(1,5)$ MVAR \\
\hline $\begin{array}{l}\text { STATCOM SOLUTIONS } \\
\text { PTY LTD }\end{array}$ & $\mathrm{d} 105 / \mathrm{d} 315$ & $\begin{array}{l}\text { Several-Typical } \\
(200 \ldots . .265) \mathrm{V}\end{array}$ & $(5 \ldots .15)$ KVA \\
\hline ADF POWER TUNING & ADF P700 STATCOM & $(6-36) \mathrm{KV}$ & $(1 \ldots \ldots 10)$ MVA \\
\hline ADDNEW & STATCOM/SVG & $(6,10,35) \mathrm{KV}$ & (3) MVAR \\
\hline AMSC & D-VAR & Up to (46) KV & $( \pm 2 \ldots \ldots . .100 \mathrm{~s})$ MVAR \\
\hline GAMESA & STATCOM-EN & $\begin{array}{l}\text { (11.8 ... .34.5) KV } \\
\text { (Step-up Transformer) }\end{array}$ & (1.5) MVAR \\
\hline MERUSPOWER & $\begin{array}{l}\text { M-STATCOM } \\
\text { (Merus M8000) }\end{array}$ & $\begin{array}{l}\text { All voltages } \\
\text { via Transformer }\end{array}$ & (1.3) MVAR \\
\hline PONOVO & AccuVar ASVC & $(3,6,10,20,35) \mathrm{KV}$ & $\begin{array}{l}( \pm 1 \ldots \pm 18) \text { MVAR } \\
\text { ASVC-100 type }( \pm 10 \ldots \pm 50) \\
\text { MVAR ASVC-200 type }\end{array}$ \\
\hline S AND C ELECTRIC & The Purewave DSTATCOM & $(0.48 \ldots . .35) \mathrm{KV}$ & $( \pm 1.23)$ MVAR/3.3 MVAR \\
\hline SIEMENS & SVC Plus & $\begin{array}{l}\text { Up to (36) KV } \\
\text { (Transformer less) }\end{array}$ & $( \pm 25 \ldots . . \pm 50)$ MVAR \\
\hline \multicolumn{4}{|l|}{ Available sizes of SVC } \\
\hline ABB & SVC & (69) KV & $(+50 /-40)$ MVAR \\
\hline GE Power & SVC & $(33 \ldots \ldots \ldots 380) \mathrm{KV}$ & $(0 \ldots \ldots . .300)$ MVAR \\
\hline ADDNEW & FC-TCR & $(6,10,35) \mathrm{KV}$ & $(0 \ldots \ldots . .200)$ MVAR \\
\hline ADDNEW & TSC & $(6 \ldots . .10) \mathrm{KV}$ & $(0.15 \ldots \ldots . .3)$ MVAR \\
\hline ADDNEW & TCR & $(6 \ldots . .35) \mathrm{KV}$ & $(1 \ldots \ldots \ldots 150)$ MVAR \\
\hline PONOVO & SVC (FC-TCR) & $(6 \ldots . .66) \mathrm{KV}$ & $(0 \ldots \ldots . .400)$ MVAR \\
\hline RXPE & TCR & $(6,10,27.5,35,66) \mathrm{KV}$ & $(6 \ldots \ldots .300)$ MVAR \\
\hline SIEMENS & SVC classic (TSC-TCR) & $(6 \ldots \ldots 800) \mathrm{KV}$ & $(40 \ldots \ldots . .800)$ MVAR \\
\hline \multicolumn{4}{|l|}{ Available sizes of APF } \\
\hline $\begin{array}{l}\text { CONDENSATOR } \\
\text { DOMINIT GMBH }\end{array}$ & NQ2501/NQ2502 & $\begin{array}{l}\text { Several-Typical } \\
(200-480, \pm 10 \%) \mathrm{V}\end{array}$ & $(41.5 \ldots \ldots .41 .5)$ KVA \\
\hline ADF POWER TUNING & $\begin{array}{l}\text { ADF P100-70/480, } \\
\text { ADF P100-100/480, } \\
\text { ADF P100-130/480, } \\
\text { ADF P100-90/690 }\end{array}$ & $\begin{array}{l}\text { Several-Typical } \\
(208-480,480-690) \mathrm{V}\end{array}$ & $(49 \ldots \ldots .108) \mathrm{KVA}$ \\
\hline DELTA ELECTRONICS, INC & APF2000 & $(200-480) \mathrm{V}$ & (22) KVA \\
\hline SCHNEIDER & $\begin{array}{l}\text { AccuSine PCS+ (LV } \\
\text { active filters) }\end{array}$ & $(380 \ldots 690) \mathrm{V}$ & $(50 \ldots .250) \mathrm{KVA}$ \\
\hline SCHAFFNER & FN3420 ECO sine active & $(500-600) \mathrm{V}$ & \\
\hline SIEMENS & 4RF1010-3РB0 & $(380-480) \mathrm{V}$ & \\
\hline
\end{tabular}




\section{Key Analysis on Configuration and Control Structure}

Existing research on shunt APFs and STATCOM devices that focus on the reduction of components and their effects on the control strategies was reviewed. A typical analysis of the configurations and control structure techniques is presented below.

\subsection{Limitations in Configuration Structure}

The main limitations in the split DC-link power converter topology are as follows:

- In B4 inverters, the third phase is connected clearly to the middle point or neutral point of the DC-link capacitors. The DC-bus current directly charges one of the capacitors and discharges the other. These dynamics unbalance current and voltage loading between the capacitors that discharge at a faster rate than the other, thus causing high current ripple in the imbalanced output waveform [206].

- To compensate for the DC-bus voltage fluctuation issues [207], the removed single-leg terminal is connected to the negative terminal of the DC-bus PWM-VSI inverter and stops the imbalanced charging of the DC-link capacitors. Furthermore, the AC film capacitor stores the power ripples connected to the AC terminals to stop the flow of decoupling power ripples and provide balanced output currents and voltages [208].

- A large DC-link voltage variation is shown in B8 split DC-leg converter applications. Both systems are operated at the same frequency and synchronized; thus, no fundamental current flows through the shared DC link. This outcome is a limitation in addition to the low AC voltage of the individual B4 power converter coupled with the shared DC-link capacitor.

- In the three-phase system, a phase circulating current [209] flows through the DC-link capacitors. Thus, the capacitors are exposed to low-frequency harmonics, thereby limiting the use of high DC-link capacitor values. The AC-AC power converter configuration presents superior overall performance than the DC-bus midpoint configuration in terms of low THD and harmonic compensation capability because of the balanced current and voltage, as well as the minimum current ripple in the imbalanced output waveform.

\subsection{Limitations in Control Structure Techniques}

- The need for voltage feed-forward and cross-coupling in SRF is the main limitation of the control structure. The phase angle of the grid voltage is required to start the control operation.

- In the stationary reference frame, the PR controller reduces the complexity of the control structure in terms of current regulation as it has no need of the phase angle, unlike the $d q$-frame.

- The adaptive band hysteresis controller increases the complexity of the control structure in the natural reference frame. However, the deadbeat controller simplifies the control scheme. Therefore, an individual control is required in each phase in case of individual phase PLLs and grid voltage to generate the current reference.

- The hysteresis and deadbeat controllers do not consider low-order harmonics in the implementation process in harmonic compensators due to their fast dynamics.

- In practical structures, both controllers require a sampling capability's hardware to compensate the positive sequence and need two filters, two transformation modules, and one controller, thus limiting its practical application in the $d q$-frame.

- Table 11 illustrates the strengths and weaknesses of the APF control techniques $[115,210,211]$. 
Table 11. Strengths and weaknesses of APF/STATCOM control techniques.

\begin{tabular}{|c|c|c|}
\hline METHOD & STRENGTH & WEAKNESS \\
\hline PI-Controller & $\begin{array}{ll}\text { - } & \text { Simple design and implementation } \\
\text { - } & \text { No complex circuit } \\
\text { - } & \text { Fast response time } \\
\text { - } & \text { Minimum Fluctuation }\end{array}$ & $\begin{array}{l}\text { - } \quad \text { Limitation of the control } \\
\text { bandwidth with harmonic } \\
\text { currents at high-frequency signals } \\
\text { - } \quad \text { Show limitation in the feedback } \\
\text { system with constant parameters }\end{array}$ \\
\hline Hysteresis Control & $\begin{array}{ll}\text { - } & \text { light system of reckoning } \\
\text { - } & \text { Simple, robust, cost effective and } \\
\text { - } & \text { Fasy implementation } \\
\text { - } & \text { Fast speed of control loop } \\
\text { - } & \text { No need of oscillator or error amplifier }\end{array}$ & $\begin{array}{ll}\text { - } & \text { High switching losses for small } \\
\text { hysteresis band } \\
\text { - } & \text { Switching frequency variation and } \\
\text { large frequency variations } \\
\text { - } \quad \text { Problem in filter design } \\
\text { - } \quad \text { Phases interferences } \\
\text { - } \quad \text { Resonance problems }\end{array}$ \\
\hline Dead-Beat Control & $\begin{array}{ll}\text { - } & \text { Fast control response } \\
\text { - } & \text { Wireless transmission } \\
\text { - } & \text { Fast transient response with low THD in } \\
& \text { the lower sampling frequency }\end{array}$ & $\begin{array}{l}\text { - Control operation is depended on } \\
\text { the data of the APF parameters } \\
\text { Requires a precise model of the } \\
\text { filter to reach the } \\
\text { desired performance. } \\
\text { - Sensitive to the parametric } \\
\text { variations of the controlled system } \\
\text { and high THD for nonlinear loads }\end{array}$ \\
\hline Reference Prediction & - $\quad$ Problem with static loads & - $\quad$ Filtering effect with load changing \\
\hline Multi-rate Sampling & $\begin{array}{ll}- & \text { Fast response } \\
- & \text { fast discretization in control variables }\end{array}$ & $\begin{array}{l}\text { - } \quad \text { Need fast control devices like } \\
\text { FPGAs, AD converters } \\
\text { - } \quad \text { Slow-sampling rate }\end{array}$ \\
\hline Phase-angle Correction & - $\quad$ Delay effect & Take more time in calculation \\
\hline One Cycle Control & $\begin{array}{l}\text { - } \quad \text { Simple design with flip-flops, comparators } \\
\text { and clock } \\
\text { - } \quad \text { Better tracing transient waveform } \\
\text { - } \quad \text { Good time and dynamic response }\end{array}$ & 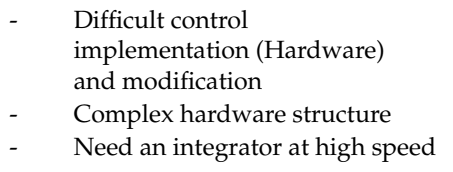 \\
\hline Adaptive Neural Network & $\begin{array}{l}\text { - } \quad \text { Does not require statistical training } \\
\text { - } \quad \text { No need underlying input data distribution } \\
\text { - } \quad \text { Can used a wide variety of functions and } \\
\text { capture different patterns } \\
\text { - They are the actual human operating system }\end{array}$ & 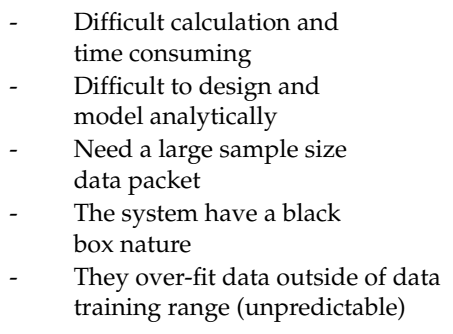 \\
\hline $\begin{array}{l}\text { Neural-Network } \\
\text { Predicting Reference }\end{array}$ & $\begin{array}{ll}\text { - } & \text { Active compensation among loads } \\
\text { - } & \text { Simple design and satisfactory accuracy } \\
\text { - } & \text { Mutual methods and faster control } \\
\text { parameters adaptation }\end{array}$ & $\begin{array}{ll}\text { - } & \text { Needed DC-link } \\
\text { load measurement } \\
\text { - } & \text { Not implemented in } \\
\text { unknown load } \\
\text { - } \quad \begin{array}{l}\text { Needed large number } \\
\text { of parameters }\end{array} \\
\text { - } \quad \text { Performance evaluation, stuck in } \\
\text { local minima }\end{array}$ \\
\hline $\begin{array}{l}\text { Selective } \\
\text { Harmonics Compensation }\end{array}$ & - $\quad$ Parameters are frequency depended & $\begin{array}{l}\text { - } \quad \text { Power increase with the } \\
\text { harmonic compensation }\end{array}$ \\
\hline
\end{tabular}


Table 11. Cont.

\begin{tabular}{|c|c|c|}
\hline METHOD & STRENGTH & WEAKNESS \\
\hline Master-Slave Control & 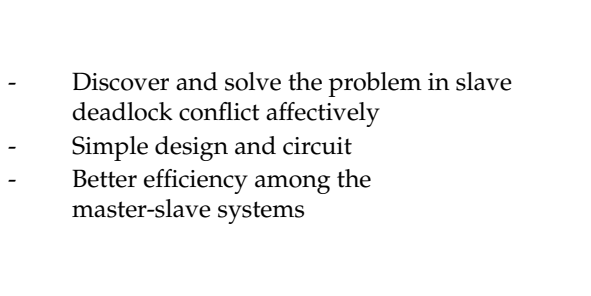 & $\begin{array}{l}\text { - } \quad \begin{array}{l}\text { Master should be built robust } \\
\text { and powerful }\end{array} \\
\text { - } \quad \text { All system is depended upon } \\
\text { the master } \\
\text { - } \quad \text { Complex and difficult } \\
\text { master system } \\
\text { - } \quad \text { Need a high cost } \\
\text { in communication } \\
\text { - } \quad \text { Reduction in real time abilities }\end{array}$ \\
\hline Predictive Control & 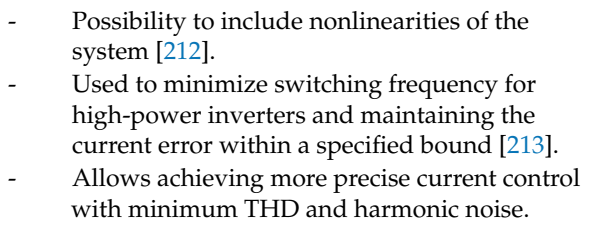 & $\begin{array}{l}\text { - Requires a precise model of the } \\
\text { filter to reach the } \\
\text { desired performance. } \\
\text { This method needs a lot } \\
\text { of calculations. }\end{array}$ \\
\hline $\begin{array}{l}\text { Sliding Mode } \\
\text { Control (SMC) }\end{array}$ & $\begin{array}{l}\text { Exhibits reliable performance during transients. } \\
\text { Shows an acceptable THD if it is designed well. }\end{array}$ & $\begin{array}{l}\text { - The problem of the Chattering } \\
\text { Phenomenon in } \\
\text { discrete implementation. } \\
\text { The difficulty of designing } \\
\text { a controller for both a good } \\
\text { transient and zero steady } \\
\text { state performance. }\end{array}$ \\
\hline Fuzzy Control Methods & $\begin{array}{l}\text { Insensitive to parametric variations and } \\
\text { operation points. } \\
\text { - Sophisticated technique, easy to design and } \\
\text { implement a large-scale nonlinear system. }\end{array}$ & Slow control method. \\
\hline Repetitive Controller (RC) & $\begin{array}{l}\text { These controllers are implemented as harmonic } \\
\text { compensators and current controllers. They show } \\
\text { robust performance for periodic disturbances and } \\
\text { ensure a zero steady-state error at all the } \\
\text { harmonic frequencies. }\end{array}$ & $\begin{array}{l}\text { Is not easy to stabilize for all unknown } \\
\text { load disturbances and cannot obtain } \\
\text { very fast response for fluctuating load. }\end{array}$ \\
\hline
\end{tabular}

\subsection{Key Findings}

The following are the shortcomings of the current research as revealed by the review:

(1) In parallel inverter topology, the output voltage per phase at different frequencies generates transitions, which block the forbidden states. This voltage effectively limits the range of reference amplitudes and phase shifts.

(2) Generally, in reduced switch count power converters, the modulation strategy adopted is SPWM to switch and compensate for the DC-bus voltage fluctuation issues [214]. By contrast, in reduced switch count converters, the phase shift does not track the three-phase balance reference signal in the symmetry order.

(3) Switch reduction generally leads to interdependencies between AC input and output frequencies, unlike full-bridge converters. This restriction limits the references for modulation in operating the power converters at the same frequency. Voltage doubling and semiconductor stress are not issues in the B4 converter, unlike in the nine-switch $\mathrm{H} 6$ converter, because of the favorable maximum modulation ratio of unity [215].

(4) Reduced switch count (four-switch) topologies face more limitations in their switching states than conventional six-switch converters. Findings indicate that the removed leg terminal that is connected to either the upper positive DC-link terminal or the lower negative DC-link terminal is not achievable. 
(5) In the B6 converter, two switching states, $(0,0)$ and $(1,1)$, are stated as zero vectors, which stop the flow of the current toward the load. In the B4 converter, the current flows even in zero-vector states. Therefore, in two other switching states, $(0,1)$ and $(1,0)$, the resulting uncontrolled current flows through the common phase because of the direct connection between the DC-link capacitor and the AC terminal.

(6) The PLL synchronizes the power inverter modulation to the power grid and provides freedom in designing the modulation index caused by phasing the angle in between the grids and by modulating waves to adjust the maximum magnitude for unity output.

(7) Eliminating the active switches creates an unequal thermal distribution among the remaining switches at the expense of reduced structure, conduction losses, switching losses, and low system cost.

(8) In the split converter, the third-phase current flows directly through DC-link capacitors, thus exposing the converter to low-frequency harmonics, which need a high-value-rated capacitor.

(9) In the two-leg rectifier (multiply by $2 / \mathrm{pi}=0.6$ ), the output power gain is lower than that of the three-leg rectifier (multiply by 1.6), thereby increasing the current rating of the active switching components.

\section{Upcoming Trends}

The new trend in the field of power electronics aims to minimize the number of power semiconductor components, such as IGBT switches, to reduce the overall price of power converter devices. Designing cost-effective topologies on the basis of the reduced number of semiconductor devices in the range of 10 kilowatts and above has always been attractive to researchers. From these facts, the transformerless system is showing important developments toward a mature level. With advancements in microprocessors, controllers, and fast switching devices, long-lasting and proficient APF/STATCOM systems have been proposed with highly rated megawatt ranges, improved performance, enhanced efficiency, and most importantly, low costs for varying applications. Moreover, reduced switch count inverter topologies limit the cost, size, switching losses, and complexity of the control structure, as well as the algorithm and interface circuits. Similarly, new growth in efficient modulation techniques can help guarantee high reliability, fast transient and dynamic response, low THD, excellent harmonic and reactive power compensation, and current and voltage regulation of power electronics.

New trends in hybrid topologies aim to develop advanced APF and STATCOM systems that have low-rated power component systems and added dual functionality for improved performance. Similarly, a technology for achieving new growth in multilevel power inverters on the basis of the reduced number of components is becoming a popular research direction. The excessive penetration of renewable devices in the power transmission network creates various power quality challenges for engineers and researchers. However, FACTS devices, such as STATCOMs, SVCs, and DSTATCOMs, have been successful in mitigating the issues of power quality, including voltage sags, transients, harmonics, and damping oscillations. Further research and improvements in APF technology have recently been performed in terms of dual-terminal inverters, shared legs between inverters, and rectifiers to substitute for split-capacitor configurations. Consequently, next-generation power semiconductor devices and packaging of silicon carbide ( $\mathrm{SiC}$ ) IGBT power modules with Schottky barrier diode modules, integrated gate-commutated thyristor modules, and SiC MOSFET can be effectively used.

\section{Conclusions}

This paper discussed the topological and control schemes of APF and STATCOM devices. A transformerless and reduced switch count structure for power converters and control strategies were reviewed. A discussion about development stages in configuration with respect to low cost, low volumetric size and weight, compact structure, and high reliability was given. Different grid-connected 
control schemes, and their implementation structures, as well as the extraction of harmonic reference signals, were presented. This review discussed different devices, namely, PFs, shunt APFs, shunt hybrid filters, STATCOMs, SVCs, UPQCs, and DSTATCOMs, all of which are typically used to enhance power quality and mitigation of load harmonics. Dual-terminal inverters, transformerless, multilevel inverters, shared legs between inverters, shared legs between rectifiers, split capacitor configurations, and new-generation semiconductor devices deserve future research attention. Finally, simulation and experimental results verified the effectiveness of APF/STATCOM topologies for harmonic mitigation in accordance with IEEE-519.

Author Contributions: All the authors contributed in completing the Paper. The main idea of the paper was presented by W.U.K.T. while M.A., M.S. and B.H. helped in accumulating the research data in this review paper. M.A.M. and N.B. prepared the format of the paper. S.M. and M.N. is the head of research team.

Acknowledgments: The authors would like to acknowledge the financial support received from the University of Malaya, Malaysia, through Frontier Research Grant No. FG007-17AFR and Innovative Technology Grant No. RP043B-17AET.

Conflicts of Interest: The authors declare no conflict of interest.

\section{Abbreviations}

$\begin{array}{ll}\text { APF } & \text { Active power filters } \\ \text { B4 } & \text { Four-switch inverter } \\ \text { CSI } & \text { Current-fed-type inverters } \\ \text { CHB } & \text { Cascaded H-bridge } \\ \text { DFT } & \text { Discrete Fourier transform } \\ \text { DSP } & \text { Digital signal processor } \\ \text { dSpace } & \text { Digital Signal Processor for Applied and Control Engineering } \\ \text { DSTATCOM } & \text { Distribution STATCOM } \\ \text { DQ } & \text { Synchronous Fundamental Frame } \\ \text { DVR } & \text { Dynamic voltage restorer } \\ \text { ESS } & \text { Energy storage system } \\ \text { FACTS } & \text { Flexible AC transmission system } \\ \text { FFT } & \text { Fast Fourier transform } \\ \text { GPGA } & \text { Field programmable gate array } \\ \text { HAPFs } & \text { Hybrid APF } \\ \text { HF } & \text { High frequency } \\ \text { HPF } & \text { High pass filter } \\ \text { HV } & \text { High voltage } \\ \text { IEEE } & \text { Institute of Electrical and Electronics Engineers } \\ \text { IEC } & \text { International Electro-technical Commission } \\ \text { IGBT } & \text { Insulated-gate bipolar transistors } \\ \text { ITC } & \text { Indirect torque control } \\ \text { Ki } & \text { Integral gain } \\ \text { Kp } & \text { Proportional gain } \\ \text { LPF } & \text { Low pass filter } \\ \text { LVRT } & \text { Low-voltage ride through } \\ \text { MLI } & \text { Multilevel inverter } \\ \text { MOSFET } & \text { Metal-oxide-semiconductor field-effect transistor } \\ \text { MPP } & \text { Maximum power point } \\ \text { PCC } & \text { Point of common coupling } \\ \text { PF } & \text { Passive filter } \\ \text { PI } & \text { Proportional integral controller } \\ \text { PLL } & \text { Phase locked loop } \\ \text { PQ } & \text { Instantaneous power theory } \\ \text { PV } & \text { Photovoltaic } \\ & \end{array}$




$\begin{array}{ll}\text { PWM } & \text { Pulse width modulation } \\ \text { RC } & \text { Repetitive Controller } \\ \text { RDFT } & \text { Recursive discrete Fourier Transform } \\ \text { SAPF } & \text { Shunt active power filter } \\ \text { SBD } & \text { Schottky barrier diode } \\ \text { SHE } & \text { Selective harmonic elimination } \\ \text { SiC } & \text { Silicon carbide } \\ \text { SMC } & \text { Sliding Mode Control } \\ \text { SOFC } & \text { Solid oxide fuel call } \\ \text { SPWM } & \text { Sinusoidal Pulse Width Modulation } \\ \text { SRF } & \text { Synchronous-reference-frame } \\ \text { STATCOM } & \text { static compensator } \\ \text { SVC } & \text { Static volt-ampere reactive VAR compensator } \\ \text { SVM } & \text { Space vector modulation } \\ \text { SVPWM } & \text { Space vector Pulse Width Modulation } \\ \text { TCR } & \text { Thyristor-controlled resistor } \\ \text { THD } & \text { Total Harmonic Distortion } \\ \text { UPQC } & \text { Unified power quality conditioner (UPQC) } \\ \text { VSC } & \text { Voltage Source Converter } \\ \text { VSI } & \text { Voltage-fed-type inverters } \\ \text { WT } & \text { Wind turbine } \\ \text { 1P2W } & \text { Single-phase two-wire } \\ \text { 3P3W } & \text { Three-phase three-wire } \\ \text { 3P4W } & \text { Three-phase four-wire } \\ \text { 3P4L } & \text { Three phase four-leg } \\ \end{array}$

\section{References}

1. Singh, B.; Al-Haddad, K.; Chandra, A. A review of active filters for power quality improvement. IEEE Trans. Ind. Electron. 1999, 46, 960-971. [CrossRef]

2. Hamadi, A.; Rahmani, S.; Al-Haddad, K. A Hybrid Passive Filter Configuration for VAR Control and Harmonic Compensation. IEEE Trans. Ind. Electron. 2010, 57, 2419-2434. [CrossRef]

3. Bhattacharya, A.; Chakraborty, C.; Bhattacharya, S. Shunt compensation. IEEE Ind. Electron. Mag. 2009, 3, 38-49. [CrossRef]

4. Sirjani, R.; Rezaee Jordehi, A. Optimal placement and sizing of distribution static compensator (D-STATCOM) in electric distribution networks: A review. Renew. Sustain. Energy Rev. 2017, 77, 688-694. [CrossRef]

5. Beres, R.N.; Wang, X.; Liserre, M.; Blaabjerg, F.; Bak, C.L. A review of passive power filters for three-phase grid-connected voltage-source converters. IEEE J. Emerg. Sel. Top. Power Electron. 2016, 4, 54-69. [CrossRef]

6. Ringwood, J.V.; Simani, S. Overview of modelling and control strategies for wind turbines and wave energy devices: Comparisons and contrasts. Annu. Rev. Control 2015, 40, 27-49. [CrossRef]

7. Ahmed, K.H.; Finney, S.J.; Williams, B.W. Passive filter design for three-phase inverter interfacing in distributed generation. In Proceedings of the Compatibility in Power Electronics, Gdansk, Poland, 29 May-1 June 2007; pp. 1-9.

8. Lam, C.S.; Choi, W.H.; Wong, M.C.; Han, Y.D. Adaptive DC-Link Voltage-Controlled Hybrid Active Power Filters for Reactive Power Compensation. IEEE Trans. Power Electron. 2012, 27, 1758-1772. [CrossRef]

9. Espi, J.; Garcia-Gil, R.; Castello, J. Capacitive Emulation for LCL-Filtered Grid-Connected Converters. Energies 2017, 10, 930. [CrossRef]

10. Litran, S.P.; Salmeron, P. Analysis and design of different control strategies of hybrid active power filter based on the state model. IET Power Electron. 2012, 5, 1341-1350. [CrossRef]

11. Prakash Mahela, O.; Gafoor Shaik, A. Topological aspects of power quality improvement techniques: A comprehensive overview. Renew. Sustain. Energy Rev. 2016, 58, 1129-1142. [CrossRef]

12. Mithulananthan, N.; Canizares, C.A.; Reeve, J.; Rogers, G.J. Comparison of PSS, SVC, and STATCOM controllers for damping power system oscillations. IEEE Trans. Power Syst. 2003, 18, 786-792. [CrossRef] 
13. Colak, I.; Kabalci, E.; Fulli, G.; Lazarou, S. A survey on the contributions of power electronics to smart grid systems. Renew. Sustain. Energy Rev. 2015, 47, 562-579. [CrossRef]

14. Singh, B.; Solanki, J. A Comparison of Control Algorithms for DSTATCOM. IEEE Trans. Ind. Electron. 2009, 56, 2738-2745. [CrossRef]

15. Singh, B.; Mukherjee, V.; Tiwari, P. A survey on impact assessment of DG and FACTS controllers in power systems. Renew. Sustain. Energy Rev. 2015, 42, 846-882. [CrossRef]

16. Tokiwa, A.; Yamada, H.; Tanaka, T.; Watanabe, M.; Shirai, M.; Teranishi, Y. New Hybrid Static VAR Compensator with Series Active Filter. Energies 2017, 10, 1617. [CrossRef]

17. Qazi, S.H.; Mustafa, M.W. Review on active filters and its performance with grid connected fixed and variable speed wind turbine generator. Renew. Sustain. Energy Rev. 2016, 57, 420-438. [CrossRef]

18. Tareen, W.U.K.; Mekhilef, S.; Nakaoka, M. A transformerless reduced switch counts three-phase APF-assisted smart EV charger. In Proceedings of the 2017 IEEE Applied Power Electronics Conference and Exposition (APEC), Tampa, FL, USA, 26-30 March 2017; pp. 3307-3312.

19. Jordehi, A.R. Particle swarm optimisation (PSO) for allocation of FACTS devices in electric transmission systems: A review. Renew. Sustain. Energy Rev. 2015, 52, 1260-1267. [CrossRef]

20. Shmilovitz, D. On the definition of total harmonic distortion and its effect on measurement interpretation. IEEE Trans. Power Deliv. 2005, 20, 526-528.

21. Barros, J.; Diego, R.I. A review of measurement and analysis of electric power quality on shipboard power system networks. Renew. Sustain. Energy Rev. 2016, 62, 665-672. [CrossRef]

22. Lascu, C.; Asiminoaei, L.; Boldea, I.; Blaabjerg, F. High Performance Current Controller for Selective Harmonic Compensation in Active Power Filters. IEEE Trans. Power Electron. 2007, 22, 1826-1835. [CrossRef]

23. Kanjiya, P.; Khadkikar, V.; Zeineldin, H.H. Optimal Control of Shunt Active Power Filter to Meet IEEE Std. 519 Current Harmonic Constraints Under Nonideal Supply Condition. IEEE Trans. Ind. Electron. 2015, 62, 724-734. [CrossRef]

24. Bollen, M.H. What is power quality? Electr. Power Syst. Res. 2003, 66, 5-14. [CrossRef]

25. Mahela, O.P.; Shaik, A.G.; Gupta, N. A critical review of detection and classification of power quality events. Renew. Sustain. Energy Rev. 2015, 41, 495-505. [CrossRef]

26. Khadem, S.K.; Basu, M.; Conlon, M.F. Parallel operation of inverters and active power filters in distributed generation system-A review. Renew. Sustain. Energy Rev. 2011, 15, 5155-5168. [CrossRef]

27. Wang, Y.; Kuckelkorn, J.; Zhao, F.-Y.; Spliethoff, H.; Lang, W. A state of art of review on interactions between energy performance and indoor environment quality in Passive House buildings. Renew. Sustain. Energy Rev. 2017, 72, 1303-1319. [CrossRef]

28. Büyük, M.; Tan, A.; Tümay, M.; Bayındır, K.Ç. Topologies, generalized designs, passive and active damping methods of switching ripple filters for voltage source inverter: A comprehensive review. Renew. Sustain. Energy Rev. 2016, 62, 46-69. [CrossRef]

29. Wu, J.-C.; Jou, H.-L.; Wu, K.-D.; Hsiao, H.-H. Three-phase four-wire hybrid power filter using a smaller power converter. Electr. Power Syst. Res. 2012, 87, 13-21. [CrossRef]

30. Bouzelata, Y.; Kurt, E.; Altın, N.; Chenni, R. Design and simulation of a solar supplied multifunctional active power filter and a comparative study on the current-detection algorithms. Renew. Sustain. Energy Rev. 2015, 43, 1114-1126. [CrossRef]

31. Mehrasa, M.; Pouresmaeil, E.; Zabihi, S.; Rodrigues, E.M.G.; Catalão, J.P.S. A control strategy for the stable operation of shunt active power filters in power grids. Energy 2016, 96, 325-334. [CrossRef]

32. Mohd Zainuri, M.; Mohd Radzi, M.; Che Soh, A.; Mariun, N.; Abd Rahim, N.; Teh, J.; Lai, C.-M. Photovoltaic Integrated Shunt Active Power Filter with Simpler ADALINE Algorithm for Current Harmonic Extraction. Energies 2018, 11, 1152. [CrossRef]

33. Qiao, W.; Harley, R.G.; Venayagamoorthy, G.K. Coordinated Reactive Power Control of a Large Wind Farm and a STATCOM Using Heuristic Dynamic Programming. IEEE Trans. Energy Convers. 2009, 24, 493-503. [CrossRef]

34. De la Villa Jaen, A.; Acha, E.; Exposito, A.G. Voltage Source Converter Modeling for Power System State Estimation: STATCOM and VSC-HVDC. IEEE Trans. Power Syst. 2008, 23, 1552-1559. [CrossRef]

35. Arsoy, A.B.; Liu, Y.; Ribeiro, P.F.; Wang, F. StatCom-SMES. IEEE Ind. Appl. Mag. 2003, 9, 21-28. [CrossRef]

36. Pathak, A.K.; Sharma, M.P.; Bundele, M. A critical review of voltage and reactive power management of wind farms. Renew. Sustain. Energy Rev. 2015, 51, 460-471. [CrossRef] 
37. Singh, B.; Saha, R.; Chandra, A.; Al-Haddad, K. Static synchronous compensators (STATCOM): A review. IET Power Electron. 2009, 2, 297-324. [CrossRef]

38. Adamczyk, A.G.; Teodorescu, R.; Rodriguez, P.; Mukerjee, R.N. FACTS devices for large wind power plants. In Proceedings of the EPE Wind Energy Chapter Symposium, Stafford, UK, 15-16 April 2010.

39. Belouda, M.; Jaafar, A.; Sareni, B.; Roboam, X.; Belhadj, J. Integrated optimal design and sensitivity analysis of a stand alone wind turbine system with storage for rural electrification. Renew. Sustain. Energy Rev. 2013, 28, 616-624. [CrossRef]

40. Mahela, O.P.; Shaik, A.G. A review of distribution static compensator. Renew. Sustain. Energy Rev. 2015, 50, 531-546. [CrossRef]

41. Siemens. Flexible AC Transmission Systems (FACTS), Parallel Compensation, Comprehensive Solutions for Safe and Reliable Grid Operation; Siemens: Munich, Germany, 2016.

42. Hingorani, N.G. Flexible AC transmission. IEEE Spectr. 1993, 30, 40-45. [CrossRef]

43. Habur, K.; O'Leary, D. FACTS_Flexible Alternating Current Transmission Systems: For Cost Effective and Reliable Transmission of Electrical Energy; Siemens-World Bank Document-Final Draft Report; Siemens: Erlangen, Germany, 2004.

44. Norambuena, M.; Rodriguez, J.; Kouro, S.; Rathore, A. A novel multilevel converter with reduced switch count for low and medium voltage applications. In Proceedings of the 2017 IEEE Energy Conversion Congress and Exposition (ECCE), Cincinnati, OH, USA, 1-5 October 2017; pp. 5267-5272.

45. Vijayaraja, L.; Kumar, S.G.; Rivera, M. A review on multilevel inverter with reduced switch count. In Proceedings of the 2016 IEEE International Conference on Automatica (ICA-ACCA), Curico, Chile, 19-21 October 2016; pp. 1-5.

46. Vavilapalli, S.; Padmanaban, S.; Subramaniam, U.; Mihet-Popa, L. Power Balancing Control for Grid Energy Storage System in Photovoltaic Applications-Real Time Digital Simulation Implementation. Energies 2017, 10, 928. [CrossRef]

47. Sridhar, V.; Umashankar, S. A comprehensive review on CHB MLI based PV inverter and feasibility study of CHB MLI based PV-STATCOM. Renew. Sustain. Energy Rev. 2017, 78, 138-156. [CrossRef]

48. Chang, W.-N.; Liao, C.-H. Design and Implementation of a STATCOM Based on a Multilevel FHB Converter with Delta-Connected Configuration for Unbalanced Load Compensation. Energies 2017, 10, 921. [CrossRef]

49. Varma, R.K.; Khadkikar, V.; Seethapathy, R. Nighttime Application of PV Solar Farm as STATCOM to Regulate Grid Voltage. IEEE Trans. Energy Convers. 2009, 24, 983-985. [CrossRef]

50. Varma, R.K.; Rahman, S.A.; Vanderheide, T. New Control of PV Solar Farm as STATCOM (PV-STATCOM) for Increasing Grid Power Transmission Limits During Night and Day. IEEE Trans. Power Deliv. 2015, 30, 755-763. [CrossRef]

51. Varma, R.K.; Das, B.; Axente, I.; Vanderheide, T. Optimal 24-hr utilization of a PV solar system as STATCOM (PV-STATCOM) in a distribution network. In Proceedings of the 2011 IEEE Power and Energy Society General Meeting, San Diego, CA, USA, 24-29 July 2011; pp. 1-8.

52. Junbiao, H.; Solanki, S.K.; Solanki, J.; Schoene, J. Study of unified control of STATCOM to resolve the Power quality issues of a grid-connected three phase PV system. In Proceedings of the 2012 IEEE PES Innovative Smart Grid Technologies (ISGT), Washington, DC, USA, 16-20 January 2012; pp. 1-7.

53. Seo, H.R.; Kim, G.H.; Jang, S.J.; Kim, S.Y.; Park, S.; Park, M.; Yu, I.K. Harmonics and reactive power compensation method by grid-connected Photovoltaic generation system. In Proceedings of the 2009 International Conference on Electrical Machines and Systems, Tokyo, Japan, 15-18 November 2009; pp. 1-5.

54. Demirdelen, T.; Kayaalp, R.I.; Tumay, M. Simulation modelling and analysis of modular cascaded multilevel converter based shunt hybrid active power filter for large scale photovoltaic system interconnection. Simul. Model. Pract. Theory 2017, 71, 27-44. [CrossRef]

55. Varma, R.K.; Rahman, S.A.; Sharma, V.; Vanderheide, T. Novel control of a PV solar system as STATCOM (PV-STATCOM) for preventing instability of induction motor load. In Proceedings of the 2012 25th IEEE Canadian Conference on Electrical and Computer Engineering (CCECE), Montreal, QC, Canada, 29 April-2 May 2012; pp. 1-5.

56. Toodeji, H.; Farokhnia, N.; Riahy, G.H. Integration of PV module and STATCOM to extract maximum power from PV. In Proceedings of the 2009 International Conference on Electric Power and Energy Conversion Systems, Sharjah, UAE, 10-12 November 2009; pp. 1-6. 
57. Luo, L.; Gu, W.; Zhang, X.-P.; Cao, G.; Wang, W.; Zhu, G.; You, D.; Wu, Z. Optimal siting and sizing of distributed generation in distribution systems with PV solar farm utilized as STATCOM (PV-STATCOM). Appl. Energy 2018, 210, 1092-1100. [CrossRef]

58. Zeng, Z.; Yang, H.; Zhao, R.; Cheng, C. Topologies and control strategies of multi-functional grid-connected inverters for power quality enhancement: A comprehensive review. Renew. Sustain. Energy Rev. 2013, 24, 223-270. [CrossRef]

59. Hassaine, L.; Olias, E.; Quintero, J.; Salas, V. Overview of power inverter topologies and control structures for grid connected photovoltaic systems. Renew. Sustain. Energy Rev. 2014, 30, 796-807. [CrossRef]

60. Karimi, M.; Mokhlis, H.; Naidu, K.; Uddin, S.; Bakar, A.H.A. Photovoltaic penetration issues and impacts in distribution network-A review. Renew. Sustain. Energy Rev. 2016, 53, 594-605. [CrossRef]

61. Mahmud, N.; Zahedi, A. Review of control strategies for voltage regulation of the smart distribution network with high penetration of renewable distributed generation. Renew. Sustain. Energy Rev. 2016, 64, 582-595. [CrossRef]

62. Kow, K.W.; Wong, Y.W.; Rajkumar, R.K.; Rajkumar, R.K. A review on performance of artificial intelligence and conventional method in mitigating PV grid-tied related power quality events. Renew. Sustain. Energy Rev. 2016, 56, 334-346. [CrossRef]

63. Vivas, J.H.; Bergna, G.; Boyra, M. Comparison of multilevel converter-based STATCOMs. In Proceedings of the 2011 14th European Conference on Power Electronics and Applications, Birmingham, UK, 30 August-1 September 2011; pp. 1-10.

64. Agrawal, R.; Jain, S. Comparison of reduced part count multilevel inverters (RPC-MLIs) for integration to the grid. Int. J. Electr. Power Energy Syst. 2017, 84, 214-224. [CrossRef]

65. Najjar, M.; Moeini, A.; Bakhshizadeh, M.K.; Blaabjerg, F.; Farhangi, S. Optimal Selective Harmonic Mitigation Technique on Variable DC Link Cascaded H-Bridge Converter to Meet Power Quality Standards. IEEE J. Emerg. Sel. Top. Power Electron. 2016, 4, 1107-1116. [CrossRef]

66. Haw, L.K.; Dahidah, M.S.A.; Almurib, H.A.F. SHE-PWM Cascaded Multilevel Inverter With Adjustable DC Voltage Levels Control for STATCOM Applications. IEEE Trans. Power Electron. 2014, 29, 6433-6444. [CrossRef]

67. Song, W.; Huang, A.Q. Fault-Tolerant Design and Control Strategy for Cascaded H-Bridge Multilevel Converter-Based STATCOM. IEEE Trans. Ind. Electron. 2010, 57, 2700-2708. [CrossRef]

68. Yiqiao, L.; Nwankpa, C.O. A new type of STATCOM based on cascading voltage-source inverters with phase-shifted unipolar SPWM. IEEE Trans. Ind. Appl. 1999, 35, 1118-1123. [CrossRef]

69. Gultekin, B.; Gercek, C.O.; Atalik, T.; Deniz, M.; Bicer, N.; Ermis, M.; Kose, K.N.; Ermis, C.; Koc, E.; Cadirci, I.; et al. Design and Implementation of a 154-kV \pm 50-Mvar Transmission STATCOM Based on 21-Level Cascaded Multilevel Converter. IEEE Trans. Ind. Appl. 2012, 48, 1030-1045. [CrossRef]

70. Gultekin, B.; Ermis, M. Cascaded Multilevel Converter-Based Transmission STATCOM: System Design Methodology and Development of a $12 \mathrm{kV} \pm 12$ MVAr Power Stage. IEEE Trans. Power Electron. 2013, 28, 4930-4950. [CrossRef]

71. Nunes, W.; Encarnação, L.; Aredes, M. An Improved Asymmetric Cascaded Multilevel D-STATCOM with Enhanced Hybrid Modulation. Electronics 2015, 4, 311-328. [CrossRef]

72. De León Morales, J.; Mata-Jiménez, M.T.; Escalante, M.F. Adaptive scheme for DC voltages estimation in a cascaded H-bridge multilevel converter. Electr. Power Syst. Res. 2011, 81, 1943-1951. [CrossRef]

73. Hatano, N.; Ise, T. Control Scheme of Cascaded H-Bridge STATCOM Using Zero-Sequence Voltage and Negative-Sequence Current. IEEE Trans. Power Deliv. 2010, 25, 543-550. [CrossRef]

74. Lee, C.T.; Wang, B.S.; Chen, S.W.; Chou, S.F.; Huang, J.L.; Cheng, P.T.; Akagi, H.; Barbosa, P. Average Power Balancing Control of a STATCOM Based on the Cascaded H-Bridge PWM Converter with Star Configuration. IEEE Trans. Ind. Appl. 2014, 50, 3893-3901. [CrossRef]

75. Divan, D.; Moghe, R.; Prasai, A. Power Electronics at the Grid Edge: The key to unlocking value from the smart grid. IEEE Power Electron. Mag. 2014, 1, 16-22. [CrossRef]

76. Ertao, L.; Yin, X.; Zhang, Z.; Chen, Y. An Improved Transformer Winding Tap Injection DSTATCOM Topology for Medium-Voltage Reactive Power Compensation. IEEE Trans. Power Electron. 2018, 33, 2113-2126.

77. Devassy, S.; Singh, B. Modified p-q Theory Based Control of Solar PV Integrated UPQC-S. In Proceedings of the 2016 IEEE Industry Applications Society Annual Meeting, Portland, OR, USA, 2-6 October 2016. 
78. Swain, S.; Ray, P.K. Short circuit fault analysis in a grid connected DFIG based wind energy system with active crowbar protection circuit for ridethrough capability and power quality improvement. Int. J. Electr. Power Energy Syst. 2017, 84, 64-75. [CrossRef]

79. Bayindir, R.; Colak, I.; Fulli, G.; Demirtas, K. Smart grid technologies and applications. Renew. Sustain. Energy Rev. 2016, 66, 499-516. [CrossRef]

80. Mansoor, M.; Mariun, N.; Toudeshki, A.; Abdul Wahab, N.I.; Mian, A.U.; Hojabri, M. Innovating problem solving in power quality devices: A survey based on Dynamic Voltage Restorer case (DVR). Renew. Sustain. Energy Rev. 2017, 70, 1207-1216. [CrossRef]

81. Jaalam, N.; Rahim, N.A.; Bakar, A.H.A.; Tan, C.; Haidar, A.M.A. A comprehensive review of synchronization methods for grid-connected converters of renewable energy source. Renew. Sustain. Energy Rev. 2016, 59, 1471-1481. [CrossRef]

82. Crosier, R.; Wang, S.; Jamshidi, M. A 4800-V grid-connected electric vehicle charging station that provides STACOM-APF functions with a bi-directional, multi-level, cascaded converter. In Proceedings of the 2012 Twenty-Seventh Annual IEEE Applied Power Electronics Conference and Exposition (APEC), Orlando, FL, USA, 5-9 February 2012; pp. 1508-1515.

83. Saqib, M.A.; Saleem, A.Z. Power-quality issues and the need for reactive-power compensation in the grid integration of wind power. Renew. Sustain. Energy Rev. 2015, 43, 51-64. [CrossRef]

84. Patrao, I.; Figueres, E.; González-Espín, F.; Garcerá, G. Transformerless topologies for grid-connected single-phase photovoltaic inverters. Renew. Sustain. Energy Rev. 2011, 15, 3423-3431. [CrossRef]

85. Llorente Iglesias, R.; Lacal Arantegui, R.; Aguado Alonso, M. Power electronics evolution in wind turbines-A market-based analysis. Renew. Sustain. Energy Rev. 2011, 15, 4982-4993. [CrossRef]

86. Rubio, J.L.O. Aplicaciones de los dispositivos FACTS en generadores eólicos. Técnica Ind. 2008, $276,36$.

87. Shafiullah, G.M.; Oo, A.M.T.; Shawkat Ali, A.B.M.; Wolfs, P. Potential challenges of integrating large-scale wind energy into the power grid-A review. Renew. Sustain. Energy Rev. 2013, 20, 306-321. [CrossRef]

88. Chen, Z.; Guerrero, J.M.; Blaabjerg, F. A Review of the State of the Art of Power Electronics for Wind Turbines. IEEE Trans. Power Electron. 2009, 24, 1859-1875. [CrossRef]

89. Woei-Luen, C.; Yuan-Yih, H. Controller design for an induction generator driven by a variable-speed wind turbine. IEEE Trans. Energy Convers. 2006, 21, 625-635.

90. Hossain, M.J.; Pota, H.R.; Ramos, R.A. Improved low-voltage-ride-through capability of fixedspeed wind turbines using decentralised control of STATCOM with energy storage system. IET Gener. Transm. Distrib. 2012, 6, 719-730. [CrossRef]

91. Muyeen, S.M.; Takahashi, R.; Murata, T.; Tamura, J.; Ali, M.H. Application of STATCOM/BESS for wind power smoothening and hydrogen generation. Electr. Power Syst. Res. 2009, 79, 365-373. [CrossRef]

92. Hossain, M.J.; Pota, H.R.; Ugrinovskii, V.A.; Ramos, R.A. Simultaneous STATCOM and Pitch Angle Control for Improved LVRT Capability of Fixed-Speed Wind Turbines. IEEE Trans. Sustain. Energy 2010, 1, 142-151. [CrossRef]

93. Suul, J.A.; Molinas, M.; Undeland, T. STATCOM-Based Indirect Torque Control of Induction Machines During Voltage Recovery After Grid Faults. IEEE Trans. Power Electron. 2010, 25, 1240-1250. [CrossRef]

94. Molinas, M.; Suul, J.A.; Undeland, T. Low Voltage Ride Through of Wind Farms With Cage Generators: STATCOM Versus SVC. IEEE Trans. Power Electron. 2008, 23, 1104-1117. [CrossRef]

95. Popavath, L.; Kaliannan, P. Photovoltaic-STATCOM with Low Voltage Ride through Strategy and Power Quality Enhancement in a Grid Integrated Wind-PV System. Electronics 2018, 7, 51. [CrossRef]

96. Sannino, A.; Svensson, J.; Larsson, T. Power-electronic solutions to power quality problems. Electr. Power Syst. Res. 2003, 66, 71-82. [CrossRef]

97. Kasem, A.H.; El-Saadany, E.F.; El-Tamaly, H.H.; Wahab, M.A.A. Power ramp rate control and flicker mitigation for directly grid connected wind turbines. IET Renew. Power Gener. 2010, 4, 261-271. [CrossRef]

98. Yuvaraj, V.; Deepa, S.N.; Rozario, A.P.R.; Kumar, M. Improving Grid Power Quality with FACTS Device on Integration of Wind Energy System. In Proceedings of the 2011 Fifth Asia Modelling Symposium, Kuala Lumpur, Malaysia, 24-26 May 2011; pp. 157-162.

99. Howlader, A.M.; Senjyu, T. A comprehensive review of low voltage ride through capability strategies for the wind energy conversion systems. Renew. Sustain. Energy Rev. 2016, 56, 643-658. [CrossRef] 
100. Leandro, G.C.; Soares, E.L.; Rocha, N. Single-phase to three-phase reduced-switch-count converters applied to wind energy conversion systems using doubly-fed induction generator. In Proceedings of the 2017 Brazilian Power Electronics Conference (COBEP), Juiz de Fora, Brazil, 19-22 November 2017; pp. 1-6.

101. Kook, K.S.; Liu, Y.; Atcitty, S. Mitigation of the wind generation integration related power quality issues by energy storage. Electr. Power Qual. Util. J. 2006, 12, 77-82.

102. Chowdhury, M.M.; Haque, M.E.; Aktarujjaman, M.; Negnevitsky, M.; Gargoom, A. Grid integration impacts and energy storage systems for wind energy applications-A review. In Proceedings of the 2011 IEEE Power and Energy Society General Meeting, San Diego, CA, USA, 24-29 July 2011; pp. 1-8.

103. Miveh, M.R.; Rahmat, M.F.; Ghadimi, A.A.; Mustafa, M.W. Control techniques for three-phase four-leg voltage source inverters in autonomous microgrids: A review. Renew. Sustain. Energy Rev. 2016, 54, 1592-1610. [CrossRef]

104. Zhaoan, W.; Qun, W.; Weizheng, Y.; Jinjun, L. A series active power filter adopting hybrid control approach. IEEE Trans. Power Electron. 2001, 16, 301-310. [CrossRef]

105. Khadkikar, V. Enhancing Electric Power Quality Using UPQC: A Comprehensive Overview. IEEE Trans. Power Electron. 2012, 27, 2284-2297. [CrossRef]

106. Mulla, M.A.; Rajagopalan, C.; Chowdhury, A. Hardware implementation of series hybrid active power filter using a novel control strategy based on generalised instantaneous power theory. IET Power Electron. 2013, 6, 592-600. [CrossRef]

107. Salmeron, P.; Litran, S.P. Improvement of the Electric Power Quality Using Series Active and Shunt Passive Filters. IEEE Trans. Power Deliv. 2010, 25, 1058-1067. [CrossRef]

108. Shivashankar, S.; Mekhilef, S.; Mokhlis, H.; Karimi, M. Mitigating methods of power fluctuation of photovoltaic (PV) sources-A review. Renew. Sustain. Energy Rev. 2016, 59, 1170-1184. [CrossRef]

109. Rastogi, M.; Mohan, N.; Edris, A.A. Hybrid-active filtering of harmonic currents in power systems. IEEE Trans. Power Deliv. 1995, 10, 1994-2000. [CrossRef]

110. Planas, E.; Andreu, J.; Gárate, J.I.; Martínez de Alegría, I.; Ibarra, E. AC and DC technology in microgrids: A review. Renew. Sustain. Energy Rev. 2015, 43, 726-749. [CrossRef]

111. Singh, S.; Gautam, A.R.; Fulwani, D. Constant power loads and their effects in DC distributed power systems: A review. Renew. Sustain. Energy Rev. 2017, 72, 407-421. [CrossRef]

112. Ghosh, A.; Ledwich, G. A unified power quality conditioner (UPQC) for simultaneous voltage and current compensation. Electr. Power Syst. Res. 2001, 59, 55-63. [CrossRef]

113. Taher, S.A.; Afsari, S.A. Optimal location and sizing of DSTATCOM in distribution systems by immune algorithm. Int. J. Electr. Power Energy Syst. 2014, 60, 34-44. [CrossRef]

114. Kirubakaran, A.; Jain, S.; Nema, R.K. A review on fuel cell technologies and power electronic interface. Renew. Sustain. Energy Rev. 2009, 13, 2430-2440. [CrossRef]

115. Baroudi, J.A.; Dinavahi, V.; Knight, A.M. A review of power converter topologies for wind generators. Renew. Energy 2007, 32, 2369-2385. [CrossRef]

116. Balikci, A.; Akpinar, E. A multilevel converter with reduced number of switches in STATCOM for load balancing. Electr. Power Syst. Res. 2015, 123, 164-173. [CrossRef]

117. Tareen, W.U.; Mekhilef, S.; Seyedmahmoudian, M.; Horan, B. Active power filter (APF) for mitigation of power quality issues in grid integration of wind and photovoltaic energy conversion system. Renew. Sustain. Energy Rev. 2017, 70, 635-655. [CrossRef]

118. Patnaik, S.S.; Panda, A.K. Three-level H-bridge and three H-bridges-based three-phase four-wire shunt active power filter topologies for high voltage applications. Int. J. Electr. Power Energy Syst. 2013, 51, 298-306. [CrossRef]

119. Junior, R.L.S.; Lazzarin, T.B.; Barbi, I. Reduced Switch Count Step-up/Step-down Switched-Capacitor Three-Phase AC-AC Converter. IEEE Trans. Ind. Electron. 2018. [CrossRef]

120. Heydari, M.; Fatemi, A.; Varjani, A.Y. A Reduced Switch Count Three-Phase AC/AC Converter with Six Power Switches: Modeling, Analysis, and Control. IEEE J. Emerg. Sel. Top. Power Electron. 2017, 5, 1720-1738. [CrossRef]

121. Limongi, L.R.; Bradaschia, F.; Azevedo, G.M.S.; Genu, L.G.B.; Filho, L.R.S. Dual hybrid power filter based on a nine-switch inverter. Electr. Power Syst. Res. 2014, 117, 154-162. [CrossRef] 
122. Bradaschia, F.; Limongi, L.R.; Cavalcanti, M.C.; Neves, F.A.S. A generalized scalar pulse-width modulation for nine-switch inverters: An approach for non-sinusoidal modulating waveforms. Electr. Power Syst. Res. 2015, 121, 302-312. [CrossRef]

123. Heydari, M.; Varjani, A.Y.; Mohamadian, M.; Fatemi, A. Three-phase dual-output six-switch inverter. IET Power Electron. 2012, 5, 1634-1650. [CrossRef]

124. Kolar, J.W.; Friedli, T.; Rodriguez, J.; Wheeler, P.W. Review of Three-Phase PWM AC-AC Converter Topologies. IEEE Trans. Ind. Electron. 2011, 58, 4988-5006. [CrossRef]

125. Limongi, L.R.; da Silva Filho, L.R.; Genu, L.G.B.; Bradaschia, F.; Cavalcanti, M.C. Transformerless Hybrid Power Filter Based on a Six-Switch Two-Leg Inverter for Improved Harmonic Compensation Performance. IEEE Trans. Ind. Electron. 2015, 62, 40-51. [CrossRef]

126. Hyosung, K.; Seung-Ki, S. Compensation voltage control in dynamic voltage restorers by use of feed forward and state feedback scheme. IEEE Trans. Power Electron. 2005, 20, 1169-1177.

127. Luo, A.; Xu, X.; Fang, L.; Fang, H.; Wu, J.; Wu, C. Feedback-Feedforward PI-Type Iterative Learning Control Strategy for Hybrid Active Power Filter With Injection Circuit. IEEE Trans. Ind. Electron. 2010, 57, 3767-3779. [CrossRef]

128. Bhattacharya, A.; Chakraborty, C.; Bhattacharya, S. Parallel-Connected Shunt Hybrid Active Power Filters Operating at Different Switching Frequencies for Improved Performance. IEEE Trans. Ind. Electron. 2012, 59, 4007-4019. [CrossRef]

129. Lee, T.L.; Wang, Y.C.; Li, J.C.; Guerrero, J.M. Hybrid Active Filter With Variable Conductance for Harmonic Resonance Suppression in Industrial Power Systems. IEEE Trans. Ind. Electron. 2015, 62, 746-756. [CrossRef]

130. Memon, M.; Saad, M.; Mubin, M. Selective Harmonic Elimination in Multilevel Inverter using Hybrid APSO Algorithm. IET Power Electron. 2018. [CrossRef]

131. Vemuganti, H.P.; Sreenivasarao, D.; Kumar, G.S.; Spandana, A.S. Reduced carrier PWM scheme with unified logical expressions for reduced switch count multilevel inverters. IET Power Electron. 2018, 11, 912-921. [CrossRef]

132. Qin, J.; Saeedifard, M. Predictive Control of a Modular Multilevel Converter for a Back-to-Back HVDC System. IEEE Trans. Power Deliv. 2012, 27, 1538-1547.

133. Wang, H.; Liserre, M.; Blaabjerg, F. Toward Reliable Power Electronics: Challenges, Design Tools, and Opportunities. IEEE Ind. Electron. Mag. 2013, 7, 17-26. [CrossRef]

134. Gui, Y.; Lee, Y.O.; Han, Y.; Chung, C.C. Novel passivity-based controller design for Back-to-back STATCOM with asymmetrically structured converters. In Proceedings of the 2012 IEEE Power and Energy Society General Meeting, San Diego, CA, USA, 22-26 July 2012; pp. 1-6.

135. Bhattacharya, A.; Chakraborty, C.; Bhattacharya, S. A reduced switch transformer-less dual hybrid active power filter. In Proceedings of the 2009 35th Annual Conference of IEEE Industrial Electronics, Porto, Portugal, 3-5 November 2009; pp. 88-93.

136. Venet, P.; Perisse, F.; El-Husseini, M.H.; Rojat, G. Realization of a smart electrolytic capacitor circuit. IEEE Ind. Appl. Mag. 2002, 8, 16-20. [CrossRef]

137. Liu, X.; Loh, P.C.; Wang, P.; Blaabjerg, F. A Direct Power Conversion Topology for Grid Integration of Hybrid AC/DC Energy Resources. IEEE Trans. Ind. Electron. 2013, 60, 5696-5707. [CrossRef]

138. Lin, B.R.; Shih, K.L. Analysis and implementation of a softswitching converter with reduced switch count. IET Power Electron. 2010, 3, 559-570. [CrossRef]

139. Donghua, C.; Shaojun, X. Review of the control strategies applied to active power filters. In Proceedings of the 2004 IEEE International Conference on Electric Utility Deregulation, Restructuring and Power Technologies, Hong Kong, China, 5-8 April 2004; Volume 2, pp. 666-670.

140. Tripathi, S.M.; Tiwari, A.N.; Singh, D. Grid-integrated permanent magnet synchronous generator based wind energy conversion systems: A technology review. Renew. Sustain. Energy Rev. 2015, 51, 1288-1305. [CrossRef]

141. Ahmed, H.F.; Cha, H.; Khan, A.A. A Single-Phase Buck Matrix Converter With High-Frequency Transformer Isolation and Reduced Switch Count. IEEE Trans. Ind. Electron. 2017, 64, 6979-6988. [CrossRef]

142. Singh, A.R.; Patne, N.R.; Kale, V.S. Adaptive distance protection setting in presence of mid-point STATCOM using synchronized measurement. Int. J. Electr. Power Energy Syst. 2015, 67, 252-260. [CrossRef]

143. Jacobina, C.B.; de Freitas, I.S.; Lima, A.M.N. DC-Link Three-Phase-to-Three-Phase Four-Leg Converters. IEEE Trans. Ind. Electron. 2007, 54, 1953-1961. [CrossRef] 
144. Liang, J.; Green, T.C.; Feng, C.; Weiss, G. Increasing Voltage Utilization in Split-Link, Four-Wire Inverters. IEEE Trans. Power Electron. 2009, 24, 1562-1569. [CrossRef]

145. Liu, H.-B.; Mao, C.-X.; Lu, J.-M.; Wang, D. Three-phase four-wire shunt APF-STATCOM using a four-leg converter. Power Syst. Prot. Control 2010, 38, 11-17.

146. Broeck, H.W.V.D.; Wyk, J.D.V. A Comparative Investigation of a Three-Phase Induction Machine Drive with a Component Minimized Voltage-Fed Inverter under Different Control Options. IEEE Trans. Ind. Appl. 1984, IA-20, 309-320. [CrossRef]

147. Rodriguez, P.; Pindado, R.; Bergas, J. Alternative topology for three-phase four-wire PWM converters applied to a shunt active power filter. In Proceedings of the IEEE 2002 28th Annual Conference of the Industrial Electronics Society, Sevilla, Spain, 5-8 November 2002; Volume 4, pp. 2939-2944.

148. Dos Santos, E.C.; Jacobina, C.B.; Dias, J.A.A.; Rocha, N. Single-Phase to Three-Phase Universal Active Power Filter. IEEE Trans. Power Deliv. 2011, 26, 1361-1371. [CrossRef]

149. Lohia, P.; Mishra, M.K.; Karthikeyan, K.; Vasudevan, K. A Minimally Switched Control Algorithm forThree-Phase Four-Leg VSI Topology toCompensate Unbalanced and Nonlinear Load. IEEE Trans. Power Electron. 2008, 23, 1935-1944. [CrossRef]

150. Munjewar, S.S.; Thombre, S.B.; Mallick, R.K. Approaches to overcome the barrier issues of passive direct methanol fuel cell-Review. Renew. Sustain. Energy Rev. 2017, 67, 1087-1104. [CrossRef]

151. Hoon, Y.; Mohd Radzi, M.; Hassan, M.; Mailah, N. Control Algorithms of Shunt Active Power Filter for Harmonics Mitigation: A Review. Energies 2017, 10, 2038. [CrossRef]

152. Zaveri, T.; Bhalja, B.; Zaveri, N. Comparison of control strategies for DSTATCOM in three-phase, four-wire distribution system for power quality improvement under various source voltage and load conditions. Int. J. Electr. Power Energy Syst. 2012, 43, 582-594. [CrossRef]

153. Badihi, H.; Zhang, Y.; Hong, H. Active power control design for supporting grid frequency regulation in wind farms. Annu. Rev. Control 2015, 40, 70-81. [CrossRef]

154. Scali, C.; Farnesi, M. Implementation, parameters calibration and field validation of a Closed Loop Performance Monitoring system. Annu. Rev. Control 2010, 34, 263-276. [CrossRef]

155. Gonzalez, S.A.; Garcia-Retegui, R.; Benedetti, M. Harmonic Computation Technique Suitable for Active Power Filters. IEEE Trans. Ind. Electron. 2007, 54, 2791-2796. [CrossRef]

156. Tavana, M.R.; Khooban, M.-H.; Niknam, T. Adaptive PI controller to voltage regulation in power systems: STATCOM as a case study. ISA Trans. 2017, 66, 325-334. [CrossRef] [PubMed]

157. Monadi, M.; Amin Zamani, M.; Ignacio Candela, J.; Luna, A.; Rodriguez, P. Protection of AC and DC distribution systems Embedding distributed energy resources: A comparative review and analysis. Renew. Sustain. Energy Rev. 2015, 51, 1578-1593. [CrossRef]

158. Wang, B.; Cathey, J.J. DSP-controlled, space-vector PWM, current source converter for STATCOM application. Electr. Power Syst. Res. 2003, 67, 123-131. [CrossRef]

159. Bina, M.T.; Bhat, A.K.S. Averaging Technique for the Modeling of STATCOM and Active Filters. IEEE Trans. Power Electron. 2008, 23, 723-734. [CrossRef]

160. Moghadasi, A.; Sarwat, A.; Guerrero, J.M. A comprehensive review of low-voltage-ride-through methods for fixed-speed wind power generators. Renew. Sustain. Energy Rev. 2016, 55, 823-839. [CrossRef]

161. İnci, M.; Bayındır, K.Ç.; Tümay, M. Improved Synchronous Reference Frame based controller method for multifunctional compensation. Electr. Power Syst. Res. 2016, 141, 500-509. [CrossRef]

162. Cañizares, C.A.; Pozzi, M.; Corsi, S.; Uzunovic, E. STATCOM modeling for voltage and angle stability studies. Int. J. Electr. Power Energy Syst. 2003, 25, 431-441. [CrossRef]

163. De Araujo Ribeiro, R.L.; de Azevedo, C.C.; de Sousa, R.M. A Robust Adaptive Control Strategy of Active Power Filters for Power-Factor Correction, Harmonic Compensation, and Balancing of Nonlinear Loads. IEEE Trans. Power Electron. 2012, 27, 718-730. [CrossRef]

164. Amoozegar, D. DSTATCOM modelling for voltage stability with fuzzy logic PI current controller. Int. J. Electr. Power Energy Syst. 2016, 76, 129-135. [CrossRef]

165. Moghbel, M.; Masoum, M.A.S.; Fereidouni, A.; Deilami, S. Optimal Sizing, Siting and Operation of Custom Power Devices with STATCOM and APLC Functions for Real-Time Reactive Power and Network Voltage Quality Control of Smart Grid. IEEE Trans. Smart Grid 2017, PP. [CrossRef]

166. Zribi, M.; Alrifai, M.; Rayan, M. Sliding Mode Control of a Variable-Speed Wind Energy Conversion System Using a Squirrel Cage Induction Generator. Energies 2017, 10, 604. [CrossRef] 
167. Varma, R.K.; Salehi, R. SSR Mitigation with a New Control of PV Solar Farm as STATCOM (PV-STATCOM). IEEE Trans. Sustain. Energy 2017, 8, 1473-1483. [CrossRef]

168. Božiček, A.; Blažič, B.; Papič, I. Time-optimal current control with constant switching frequency for STATCOM. Electr. Power Syst. Res. 2010, 80, 925-934. [CrossRef]

169. Wang, L.; Lam, C.S.; Wong, M.C. Selective Compensation of Distortion, Unbalanced and Reactive Power of a Thyristor-Controlled LC-Coupling Hybrid Active Power Filter (TCLC-HAPF). IEEE Trans. Power Electron. 2017, 32, 9065-9077. [CrossRef]

170. Behrouzian, E.; Bongiorno, M.; Teodorescu, R. Impact of Switching Harmonics on Capacitor Cells Balancing in Phase-Shifted PWM-Based Cascaded H-Bridge STATCOM. IEEE Trans. Power Electron. 2017, 32, 815-824. [CrossRef]

171. Tareen, W.U.K.; Mekhilef, S. Three-phase Transformerless Shunt Active Power Filter with Reduced Switch Count for Harmonic Compensation in Grid-Connected Applications. IEEE Trans. Power Electron. 2018, 33, 4868-4881. [CrossRef]

172. Liu, X.; Lv, J.; Gao, C.; Chen, Z.; Chen, S. A Novel STATCOM Based on Diode-Clamped Modular Multilevel Converters. IEEE Trans. Power Electron. 2017, 32, 5964-5977. [CrossRef]

173. Mishra, S.S.; Mohapatra, A.; Satpathy, P.K. Grid Integration of Small Hydro Power Plants Based on PWM Converter and D-STATCOM. In Artificial Intelligence and Evolutionary Computations in Engineering Systems: Proceedings of ICAIECES 2016; Dash, S.S., Vijayakumar, K., Panigrahi, B.K., Das, S., Eds.; Springer: Singapore, 2017; pp. 617-631.

174. Suganthi, L.; Iniyan, S.; Samuel, A.A. Applications of fuzzy logic in renewable energy systems-A review. Renew. Sustain. Energy Rev. 2015, 48, 585-607. [CrossRef]

175. Hasani, A.; Haghjoo, F. A Secure and Setting-Free Technique to Detect Loss of Field in Synchronous Generators. IEEE Trans. Energy Convers. 2017, 32, 1512-1522. [CrossRef]

176. Athari, H.; Niroomand, M.; Ataei, M. Review and Classification of Control Systems in Grid-tied Inverters. Renew. Sustain. Energy Rev. 2017, 72, 1167-1176. [CrossRef]

177. Lu, D.; Wang, J.; Yao, J.; Wang, S.; Zhu, J.; Hu, H.; Zhang, L. Clustered Voltage Balancing Mechanism and its Control Strategy for Star-Connected Cascaded H-Bridge STATCOM. IEEE Trans. Ind. Electron. 2017, 64, 7623-7633. [CrossRef]

178. Goodwin, G.C.; Mayne, D.Q.; Chen, K.-Y.; Coates, C.; Mirzaeva, G.; Quevedo, D.E. An introduction to the control of switching electronic systems. Annu. Rev. Control 2010, 34, 209-220. [CrossRef]

179. De Rossiter Correa, M.B.; Jacobina, C.B.; da Silva, E.R.C.; Lima, A.M.N. A General PWM Strategy for Four-Switch Three-Phase Inverters. IEEE Trans. Power Electron. 2006, 21, 1618-1627. [CrossRef]

180. Moeed Amjad, A.; Salam, Z. A review of soft computing methods for harmonics elimination PWM for inverters in renewable energy conversion systems. Renew. Sustain. Energy Rev. 2014, 33, 141-153. [CrossRef]

181. Sahoo, S.; Bhattacharya, T. Phase Shifted Carrier Based Synchronized Sinusoidal PWM Techniques for Cascaded H-Bridge Multilevel Inverters. IEEE Trans. Power Electron. 2018, 33, 513-524. [CrossRef]

182. Liu, C.; Wu, B.; Zargari, N.R.; Xu, D.; Wang, J. A Novel Three-Phase Three-Leg AC/ AC Converter Using Nine IGBTs. IEEE Trans. Power Electron. 2009, 24, 1151-1160.

183. Colak, I.; Kabalci, E. Developing a novel sinusoidal pulse width modulation (SPWM) technique to eliminate side band harmonics. Int. J. Electr. Power Energy Syst. 2013, 44, 861-871. [CrossRef]

184. Zhang, Y.; Wu, X.; Yuan, X. A Simplified Branch and Bound Approach for Model Predictive Control of Multilevel Cascaded H-Bridge STATCOM. IEEE Trans. Ind. Electron. 2017, 64, 7634-7644. [CrossRef]

185. Monroy-Morales, J.; Campos-Gaona, D.; Hernández-Ángeles, M.; Peña-Alzola, R.; Guardado-Zavala, J. An Active Power Filter Based on a Three-Level Inverter and 3D-SVPWM for Selective Harmonic and Reactive Compensation. Energies 2017, 10, 297. [CrossRef]

186. Dehnavi, S.M.D.; Mohamadian, M.; Yazdian, A.; Ashrafzadeh, F. Space Vectors Modulation for Nine-Switch Converters. IEEE Trans. Power Electron. 2010, 25, 1488-1496. [CrossRef]

187. Barghi Latran, M.; Teke, A. Investigation of multilevel multifunctional grid connected inverter topologies and control strategies used in photovoltaic systems. Renew. Sustain. Energy Rev. 2015, 42, 361-376. [CrossRef]

188. Wang, W.; Luo, A.; Xu, X.; Fang, L.; Chau, T.M.; Li, Z. Space vector pulse-width modulation algorithm and DC-side voltage control strategy of three-phase four-switch active power filters. IET Power Electron. 2013, 6, 125-135. [CrossRef] 
189. Camacho, A.; Castilla, M.; Miret, J.; Vicuña, L.G.d.; Guzman, R. Positive and Negative Sequence Control Strategies to Maximize the Voltage Support in Resistive-Inductive Grids During Grid Faults. IEEE Trans. Power Electron. 2018, 33, 5362-5373. [CrossRef]

190. Jayabalan, M.; Jeevarathinam, B.; Sandirasegarane, T. Reduced switch count pulse width modulated multilevel inverter. IET Power Electron. 2017, 10, 10-17. [CrossRef]

191. Prabaharan, N.; Palanisamy, K. A comprehensive review on reduced switch multilevel inverter topologies, modulation techniques and applications. Renew. Sustain. Energy Rev. 2017, 76, 1248-1282. [CrossRef]

192. Monfared, M.; Rastegar, H.; Kojabadi, H.M. Overview of modulation techniques for the four-switch converter topology. In Proceedings of the 2008 IEEE 2nd International Power and Energy Conference, Johor Bahru, Malaysia, 1-3 December 2008; pp. 803-807.

193. Asiminoael, L.; Blaabjerg, F.; Hansen, S. Detection is key-Harmonic detection methods for active power filter applications. IEEE Ind. Appl. Mag. 2007, 13, 22-33. [CrossRef]

194. Tareen, W.U.; Mekhilef, S. Transformer-less 3P3W SAPF (three-phase three-wire shunt active power filter) with line-interactive UPS (uninterruptible power supply) and battery energy storage stage. Energy 2016, 109, 525-536. [CrossRef]

195. ADF Power Tuning. Products adf-p700-statcom. Available online: https://adfpowertuning.com/products / adf-p700-statcom (accessed on 1 July 2017).

196. AMSC (NASDAQ: AMSC). Dynamic Volt-Amp Reactive (D-VAR) Compensation Solution. Available online: http:/ / www.amsc.com/gridtec/utility_reactive_power_solutions (accessed on 15 July 2017).

197. Kato, T.; Ito, T.; Aihara, T.; Namatame, S. Development of a 20-MVA STATCOM for Flicker Suppression. Hitachi Rev. 2007, 56, 133.

198. Lyons, J.P.; Vlatkovic, V.; Espelage, P.M.; Esser, A.A.M. High Power Motor Drive Converter System and Modulation Control. U.S. Paten US5910892A, 8 July 1999.

199. Bousseau, P.; Fesquet, F.; Belhomme, R.; Nguefeu, S.; Thai, T.C. Solutions for the grid integration of wind farms-A survey. Wind Energy 2006, 9, 13-25. [CrossRef]

200. Yu, Q.; Li, P.; Liu, W.; Xie, X. Overview of STATCOM technologies. In Proceedings of the 2004 IEEE International Conference on Electric Utility Deregulation, Restructuring and Power Technologies, Hong Kong, China, 5-8 April 2004; pp. 647-652.

201. Bagnall, T.; Ritter, C.; Ronner, B.; Maibach, P.; Butcher, N.; Thurnherr, T. PCS6000 STATCOM ancillary functions: Wind park resonance damping. In Proceedings of the European Wind Energy Conference and Exhibition 2009, Marseille, France, 16-19 March 2009.

202. Xu, X.; Edmonds, M.J.; Bishop, M.; Sember, J. Application of distributed static compensators in wind farms to meet grid codes. In Proceedings of the Asia-Pacific Power and Energy Engineering Conference (APPEEC), Shanghai, China, 27-29 March 2012; pp. 1-5.

203. Jiao, Z.; Xingyan, N.; Mingjun, D.; Zefeng, Q.; Qirui, L. Research on control strategy of cascade STATCOM under unbalanced system voltage. In Proceedings of the 2012 China International Conference on Electricity Distribution (CICED), Shanghai, China, 10-14 September 2012; pp. 1-4.

204. Bryantsev, A.; Bazylev, B.; Lur'e, A.; Raichenko, M.; Smolovik, S. Compensators of reactive power for controlling and stabilizing the voltage of a high-voltage electrical network. Russ. Electr. Eng. 2013, 84, 57-64. [CrossRef]

205. Qiao, C.; Jin, T.; Smedley, K.M. One-cycle control of three-phase active power filter with vector operation. IEEE Trans. Ind. Electron. 2004, 51, 455-463. [CrossRef]

206. Kim, J.; Hong, J.; Nam, K. A Current Distortion Compensation Scheme for Four-Switch Inverters. IEEE Trans. Power Electron. 2009, 24, 1032-1040.

207. Gi-Taek, K.; Lipo, T.A. VSI-PWM rectifier/inverter system with a reduced switch count. IEEE Trans. Ind. Appl. 1996, 32, 1331-1337. [CrossRef]

208. Byoung-Kuk, L.; Tae-Hyung, K.; Ehsani, M. On the feasibility of four-switch three-phase BLDC motor drives for low cost commercial applications: Topology and control. IEEE Trans. Power Electron. 2003, 18, 164-172. [CrossRef]

209. Blaabjerg, F.; Freysson, S.; Hansen, H.H.; Hansen, S. A new optimized space-vector modulation strategy for a component-minimized voltage source inverter. IEEE Trans. Power Electron. 1997, 12, 704-714. [CrossRef]

210. Kesler, M.; Ozdemir, E. Synchronous-Reference-Frame-Based Control Method for UPQC Under Unbalanced and Distorted Load Conditions. IEEE Trans. Ind. Electron. 2011, 58, 3967-3975. [CrossRef] 
211. Angulo, M.; Ruiz-Caballero, D.A.; Lago, J.; Heldwein, M.L.; Mussa, S.A. Active Power Filter Control Strategy With Implicit Closed-Loop Current Control and Resonant Controller. IEEE Trans. Ind. Electron. 2013, 60, 2721-2730. [CrossRef]

212. Bouzid, A.M.; Guerrero, J.M.; Cheriti, A.; Bouhamida, M.; Sicard, P.; Benghanem, M. A survey on control of electric power distributed generation systems for microgrid applications. Renew. Sustain. Energy Rev. 2015, 44, 751-766. [CrossRef]

213. Rodriguez, J.; Kazmierkowski, M.P.; Espinoza, J.R.; Zanchetta, P.; Abu-Rub, H.; Young, H.A.; Rojas, C.A. State of the art of finite control set model predictive control in power electronics. IEEE Trans. Ind. Inform. 2013, 9, 1003-1016. [CrossRef]

214. Zhang, L.; Loh, P.C.; Gao, F. An Integrated Nine-Switch Power Conditioner for Power Quality Enhancement and Voltage Sag Mitigation. IEEE Trans. Power Electron. 2012, 27, 1177-1190. [CrossRef]

215. Fatemi, A.; Azizi, M.; Mohamadian, M.; Varjani, A.Y.; Shahparasti, M. Single-Phase Dual-Output Inverters With Three-Switch Legs. IEEE Trans. Ind. Electron. 2013, 60, 1769-1779. [CrossRef]

(C) 2018 by the authors. Licensee MDPI, Basel, Switzerland. This article is an open access article distributed under the terms and conditions of the Creative Commons Attribution (CC BY) license (http:/ / creativecommons.org/licenses/by/4.0/). 